\title{
De menselijke hardware en software van individuen, organisaties, bedrijfstakken en economieen
}

Citation for published version (APA):

Boone, C. A. J. J. (1999). De menselijke hardware en software van individuen, organisaties, bedrijfstakken en economieen. Maastricht University. https://doi.org/10.26481/spe.19991210cb

Document status and date:

Published: 10/12/1999

DOI:

10.26481/spe.19991210cb

Document Version:

Publisher's PDF, also known as Version of record

\section{Please check the document version of this publication:}

- A submitted manuscript is the version of the article upon submission and before peer-review. There can be important differences between the submitted version and the official published version of record.

People interested in the research are advised to contact the author for the final version of the publication, or visit the DOI to the publisher's website.

- The final author version and the galley proof are versions of the publication after peer review.

- The final published version features the final layout of the paper including the volume, issue and page numbers.

Link to publication

\footnotetext{
General rights rights.

- You may freely distribute the URL identifying the publication in the public portal. please follow below link for the End User Agreement:

www.umlib.nl/taverne-license

Take down policy

If you believe that this document breaches copyright please contact us at:

repository@maastrichtuniversity.nl

providing details and we will investigate your claim.
}

Copyright and moral rights for the publications made accessible in the public portal are retained by the authors and/or other copyright owners and it is a condition of accessing publications that users recognise and abide by the legal requirements associated with these

- Users may download and print one copy of any publication from the public portal for the purpose of private study or research.

- You may not further distribute the material or use it for any profit-making activity or commercial gain

If the publication is distributed under the terms of Article $25 \mathrm{fa}$ of the Dutch Copyright Act, indicated by the "Taverne" license above, 


\section{DE MENSELIJKE HARDWARE EN SOFTWARE VAN INDIVIDUEN, ORGANISATIES, BEDRIJFSTAKKEN EN ECONOMIEËN}

MENSELIJKE HARDWARE VAN INDIVIDUEN EN

ORGANISATIES

Christophe Boone

MENSELIJKE SOFTWARE VAN BEDRIJFSTAKKEN EN ECONOMIEËN

Arjen van Witteloostuijn 


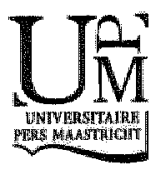

ISBN 9052782741

(C) Christophe Boone, Maastricht 2000

(C) Arjen van Witteloostuijn, Maastricht 2000 


\section{MENSELIJKE HARDWARE VAN INDIVIDUEN EN ORGANISATIES}

\section{REDE}

in verkorte vorm uitgesproken bij de aanvaarding van het ambt van hoogleraar in de bedrijfseconomie en bedrijfskunde, in het bijzonder organisatietheorie en -gedrag, aan de Faculteit der Economische Wetenschappen en Bedrijfskunde van de Universiteit Maastricht op 10 december 1999

door

Christophe Boone 
Dank aan Bert De Brabander, Woody vam Olffen en Arjen van Witteloostuijn voor het aandachtig lezen van het manuscript en hun waardevolle suggesties en commentaar.

With the birds I'll share this lonely view (Red Hot Chili Peppers, 1999) 


\section{INLEIDING}

Sta me toe eerst stil te staan bij wat ik niet ga doen in deze oratie. Hoewel het meestal verwacht wordt van een genomineerde hoogleraar, heb ik besloten geen algemeen overzicht te geven wan het vakgebied Organisatie on de heel eenvoudige reden dat de organisatiewetenschappen niet bestaan. Mijn vakgebied, dat in de Angelsaksische wereld bekend staat als organization Theory and Behavior, heeft geen welomschreven paradigma. Dit komt voornamelijk doordat onderzoekers met zeer uiteenlopende disciplinaire achtergronden zich bezig houden met de bestudering van organisaties. Dat maakt het vakgebied enerzijds uitermate boeiend maar heeft anderzijds ook als gevolg dat de kemnis nog steeds bijzonder gefragmenteerd is en dat het moeilijk is om door de bomen het bos te blijven zien (Pfeffer, 1997). De chaos wordt nog vergroot omdat veel geld kan verdiend worden in de advieswereld door zogenaamd nieuwe methoden te bedenken en aan te reilken om oude bedrijfsproblemen op te lossen. Dit heeft geleid tot een wildgroei van concepten en theorieën waarbij de verpakking dikwijls belangrijker is dan de wetenschappelijke fundering; de ene managementhype volgt dan ook de andere op. Het gevolg van dit alles is een ratjetoe van concepten, disciplines, methodologische benaderingen en theorieën. 0m met zulke gevarieerde ingrediënten een eetbaar gerecht te maken, moet men een meesterkok zijn. Dat ben ik helaas niet. Gelukkig heeft collega van Witteloostujijn - zoals hij zelf beweert een meester in plak- en knipwerk, de Linnaeus van de organisatiewetenschappen - op onnavolgbare wijze deze onmogelijke opdracht vervuld in zijn oratie Laat Duizend Bloemen Bloeien (van Witteloostuijn, 1994).

In zijn oratie houdt wan Witteloostuijn een overtuigend pleidooi voor kruisbestuiving tussen de verschillende moederdisciplines van de organisatiewetenschappen, met name economie, sociologie en psychologie. Enkel door bijdragen uit deze disciplünes te integreren kan de fragmen- 
tatie van kennis in het vakgebied een hatt worden toegeroepen en kan ons inzicht omtrent het functioneren van organisaties vergroot worden. Ik onderschriff deze overtuiging honderd procent hetgeen ook tot uiting komt in mijn eigen onderzoek dat verschillende vakgebieden bestrijkt. zoals verderop zal blijken.

In deze oratie wil ik u laten kennis maken met een deel van mijn onder zoek warrin ik verken wat de mogelijkheden zijn van de introductie van inzichten uit de persoonlijkheidspsychologie in een bedrijfseconomische context. De volgende wrasgstelling heeft mij altijd mateloos geboeid en als rode drad gediend wan mijn onderzoek: wat is de oorsprong van psychologische verschillen tussen mensen en wat zijn de gevolgen hiervan op het functioneren van sociale systemen. In deze oratie wil ik u ervan overtulgen dat alle mensen uniek zijn en dat dit uitgangspunt leidt tot belangrijke nieuwe inzichten. Eerst zal ik uiteenzetten dat het mensbeeld dat al dan niet expliciet gehanteerd wordt binnen de economische en bedrijfiskundige wetenschap, waartoe mijn vakgebied behoort, op zijn minst onvolledig is. Vervolgens zal ik met behulp van eigen onderzoek het belang van fundamentele verschillen tussen mensen in een economische context illustreren. Na een korte uitweiding over hoe dit soort onderzoek volgens mij verder zou moeten evolueren, wens ik in te gaan op enkele maatschappelijke en managementconsequenties van het gehanteerde mensbeeld.

Vöór ik van start ga wil ik eerst nog een hardnekkig gerucht dat aan deze faculteit de ronde doet de kop indrukken. Ik ben geen psycholoog maar wel een econoam van opleiding. Met deze mededeling, die $u$ op het eerste gezicht misschien overbodig lijkt, hoop ik over te brengen dat mijn onderzoek geenszins gevoed wordt door ëen of ander vooroordeel tegen economisch geinspireerd onderzoek. Ik ben dus nitet de builenstander dite andermaris nest wil bevuiten. Ik kan niet genoeg herhaten dat het mijn overtuiging is dat elke discipline in de sociale wetenschappen zinvolle dingen te zeggen heeft over het functioneren van organisaties. Het is door deze verschillende inzichten te combineren en te contrasteren dat vooruitgang in het vakgebied kan geboekt worden. 


\section{MENSBEELD}

Wanneer we over dieren spreken heeft niemand moeite om te accepteren dat er grote, diepgewortelde verschillen bestaan tussen bijvoorbeeld diverse hondensoorten wat karakter en gedrag betreft. Om niet altijd duidelijke redenen bestaat er bij vele wetenschappers een zekere terughoudendheid om deze vaststelling door te trekken naar de menselijke soort (Bouchard et al., 1990). Verschillen in opvatting hieromtrent hebben aanteiding gegeven tot een heftig, decenniadurend debat in de psychologie tussen aanhangers van de zogenaamde dispositionele versus situationele benadering. Onderwerp van discussie is het bestaan en belang van stabiele disposities of persoonlijkheidskenmerken voor de verklaring van menselijk gedrag (Epstein, 1979; Mischel, 1984; Pervin, 1985). Het debat kwam in een stroomwersnelling terecht na publicatie van een werk van Mischel Personality and Assessment in 1968. Mischel is een belangrijke proponent van de situationele benadering die stelt dat vooral de omstandigheden waarin mensen functioneren het gedrag bepalen. Hij argumenteerde dat aangezien disposities niet observeerbaar zijn, hun bestaan afgeleid moet worden uit intertemporele en cross-situationele consistentie in observeerbaar gedrag van mensen. $\mathrm{Hij}$ stelde echter vast dat wanneer objectief gemeten gedrag in éen situatie gecorreleerd wordt met objectief gedrag gemeten in een andere situatie of met scores van persoonlijkheidstesten, deze correlaties bijna nooit hoger zijn dan .30. Mischel (1968: 146) besloot hieruit het volgende:

"With the exception of intelligence, highly generalized behavioral consistencies have not been demonstrated, and the concept of personality traits as broad predispositions is thus untenable".

Deze voor aanhangers van de dispositionele benadering controversiële uitspraak leidde tot een heftige reactie. Men had vooral kritiek op de zeer restrictieve manier waarop Mischel consistentie van gedrag definieerde. Zo merkt Pervin (1985) op dat er geen enkele persoonlijkheidspsycholoog bestaat die beweert dat mensen altijd hetzelfde gedrag vertonen in om het even welke situatie zoals Mischel suggereerde. Bovendien zijn 
persoontijkheidspsychologen miet zozeer geinteresseerd in het verklaren van gedrag van mensen op microniveau in elke situatie afzonderlijk, maar wel in de coherentie van gedrag op lange termijn - geaggregeerd over verschillende situaties - en de psychologische betekenis van het gedrag voor het individu. Onderzoek toont aan dat wanneer men op deze wijze naar gediag kijkt, er systematische patronen of tendensen bestaan in het gedrag van mensen die wel goed voorspeld kunnen worden door persoonlijkheidskenmerken en dat de consistentie van het gedrag indrukwekkend kan zijin (Epstein, 1979, 1980; Funder en Colvin, 1991).

Merk ook op dat aanhangers van de situationete benadering eigenlijk twee dingen door elkaar gooien: enerzijds de waag of mensen fundamenteel van elkaar ver'schillen en anderzijds het belang hievvan voor de verklaring van het gedrag. Om het debat zuiver te voeren is het essentieel beide vragen van elkaar te scheiden omdat bevestiging van de eerste vraag niet noodzakelijk impliceert dat verschillen tussen mensen ook belangrijk zijin om gedrag te begrijpen. Laten we beginnen met het beantwoorden van de eerste vraag: verschillen mensen fundamenteel van elkaar? Erfelijkheidsonderzoek in het domein van de gedragsgenetica, toont systematisch aan dat de meeste psychologische verschillen tussen mensen gedeeltelijk erfelijk bepaald zijn. Meer bepaald blijkt uit tweeling- en verwantschapsonderzoek dat genetische verschillen gemiddeld genomen de helft van de phenotypische variatie van diverse persoonlijkheidskenmerken verklaren (Bouchard, 1994). In dit verband is het interessant het Minnesota onderzoek van gescheiden opgevoede ëéneiige tweelingen te vermelden amdat dit project een als het ware natuurlijk experiment betreft dat toelaat de erfelijke bepaaldheid van kenmerken rechtstreeks te achterhalen. Een ééneilige tweeling is namelijk genetisch identiek. Doordat ze gescheiden zijn opgevoed, kan elke gelijkenis tussen beiden niet het gevolg zijn van een gedeelde familieomgeving. Dit impliceert dat de mate van genetische variatie van een kenmerk direct kan geschat worden door de correlatie te berekenen tussen de scores van deze paren op dat kenmerk. De resultaten van dit project zijn indrukwekkend en worden door Bouchard en collega's in het tijdschrift Science als volgt samengevat (Bouchard et al., 1990: 227): 
"For almost every behavioral trait so far investigated, from reaction time to religiosity, an important fraction of the wariation among people tums out to be assaciated with genetic variation. This fact need no longer be subject to debate; rather it is time instead to consider its implications".

Deze bevindingen sluiten aan bij recent longitudinaal onderzoek naar de stabiliteit van persoonlijkheidskenmerken bij volwassenen (Costa et al. 1986: McCrae, 1993). Test-hertest correlaties van scores op diverse persoonlijkheidstesten schommelen namelijk rond een indrukwekkende .70 en dit voor tijdsintervallen wariërend van 3 tot 30 jaar. Hieruit kan ondubbelzinnig besloten worden dat de persoonlijkheid van volwassenen stabiel is. Bovendien blijkt eveneens dat het grootste deel van de instabiliteit in testscores het gevolg is varn meetfouten en niet van substantiële veranderingen in de persoonlijkheid van volwassenen (McCrae, 1993).

Uit het voorgaande kunnen we bestuiten dat er meetbare, duidelijk stabiele psychologische verschillen bestaan die, althans gedeeltelijk teruggevoerd kunnen worden tot verschillen in de genetische hardware van individuen. Fundamentele variatie die ieder wan ons zijn uniciteit verleent is een wezenlijk kenmerk van de menselijke aard. Mijn onderzoek is geinspireerd door dit inzicht en heeft tot doel te exploreren in welke mate deze variatie implicaties heeft voor het functioneren van mensen in een economische context. Ik wil echter eerst even ingaan op de mate waarin de hierboven geschetste feiten zich verhouden tot het mensbeeld dat doorgaans gehanteerd wordt aan een Faculteit Economie en/of Bedrijfskunde.

Het mensbeeld dat in de economische wetenschappen al dan niet expliciet gehanteerd wordt is dat van de homo economicus. Dit mensbeeld steunt op de volgende twee basisveronderstellingen met betrekking tot de aard van menselijk gedrag: (1) economische agenten handelen volgens het normatieve rationele model, en (2) iedere economische agent handelt, ceteris paribus, op dezelfde wijze; of met andere woorden, verschillen tussen mensen zijn irrelevant. De oorsprong van dit simplisti- 
sche mensbeeld is deels terug te voeren tot het intensieve gebruik van de deductieve methode in de economische wetenschap. Meer bepadd komt kennisgeneratie doorgaans tot stand door het afteiden van conclusies uit voorafgaandelijk geformuleerde assumpties, meestal met behulp van mathematische technieken. Eén probleem met de deductieve methode is dat de mathematische technieken soms ontoereikend kunnen zijn om analytisch de conclusies uit de assumpties af te leiden. Dit probleem neemt unteraard in omvang toe naarmate de assumpties complexer worden. Assumpties worden dan ook vaak gekozen niet omdat ze een goede weergave zouden $z$ ijn van de realtteit, maar omdat ze deductieve analyse toelaten (Harrison en Carroll, 2000). Het blijt voor een groot stuk een open vraag wat de waarde is van modellen die gebaseerd zijn op zulk een gesimplificeerd mensbeeld. Merk op dat ook gerenommeerde economen zich hierover ongerust maken. Zo hoopt Tirole (1988: 50) dat:

"... many of the conclusions of the theory of industrial organization will remain valid (at least at a descriptive level) when the profit-maximizing postulate is abandoned for a full-fetched madel of internal organization".

In experimenteel economisch onderzoek moet men regelmatig vaststellen dat geobserveerd gedrag vaak niet overeenstemt met voorspeld gedrag (Masom et al., 1991; Grether, 1992). Daarom grijpen economen de laatste jaren meer en meer naar subtielere psychologische concepties van menselijk gedrag en introduceren noties zoals altruisme, emoties (Hirshleifer en Rasmusien, 1989) en niet-rationele beslisregels in hun modellen (Grether. 1992). De introductie van deze noties heeft tot doel de eerste assumptie van normatieve rationaliteit te relaxeren en de consequenties hiervan te onderzoeken. Er werd echter nauwelijks aandacht besteed aan de relaxatie van de tweede assumptie, met name dat verschillen tussen mensen niet zomaar als ruis kunnen beschouwd worden. Behoudens een aantal studies over de effecten van verschillen tussen mannen en vrouwen, en opleiding (zie bijwoorbeeld Mason et al., 1991; Frank et al., 1993), is mij geen onderzoek bekend waarin systematisch de effecten van verschillen tussen mensen geẻxploreerd worden. 
In de bedrijfskunde komt kennisaccumulatie vooral tot stand met behulp van de inductieve methode. Dit betekent dat inzicht bekomen wordt door éen of meerdere gevallen te observeren en variabelen te meten om vervol gens relaties tussen deze variabelen te analyseren. Het is duidelijk dat de inductieve methode geen vereenvoudiging van assumpties van menselijk getrag vereist om tot zinvolle resultaten te komen. Vandaar dat het mensbeeld dat in de bedrijfskundig- en organisatiegetinte wetenschappen gehanteerd wordt, meestal dichter aanleunt bij de mens zoals hij is en bijgevolg minder simplistisch is dan dat wan de economische wetenschappen. Nochtans wordt ook in deze tak van de sociale wetenschappen relatief minder aandacht besteed aan systematisch onderzoek maar de effecten wan verschillen tussen mensen. Hoe komt dit? Twee redenen kunnen hiervoor aangehaald worden. Ten eerste worden de organisatiewetenschappen gedomineerd door theorieën op macroniveau die tot doel hebben het functioneren van organisaties als geheel te begrijpen (Sörensen, 1999; Astley en Van de Ven, 1983; March en Simon, 1958). Ten tweede heeft de klassieke systeem-structurele benadering een enorme blijvende impact gehad op de ontwikkeling van de organisatieweterschappen. Ondanks de huidige theoretische pluriformiteit (Astley en Van de Ven, 1983), heeft deze school nog steeds een dominante positie in het vakgebied. In deze sociologische benadering is er om theoretische redenen, zoats zal blijken, geen plaats voor verschillen tussen mensen.

De systeem-structurele benadering, welke zijn oorsprong vindt in de jaren dertig, beschouwt organisaties als systemen die ontworpen worden om organisatiedoelen te realiseren. Het werk wordt zodanig gestructureerd dat iedere deelactiviteit functioneel is voor de realisatie van het einddoel. De bouwstenen van de organisatiestructuur zijn de rollen welke de plichten, verantwoordelijkheden en verwachtingen van anderen definiëren. Mensen in organisaties bekleden posities waarin ze een welbepaalde rol moeten spelen om collectieve actie mogelijk te maken. De druk die uitgaat van deze externe omstandigheden op het gedrag van mensen maakt verschillen tussen mensen volgens dit mensbeeld irrelevant; kenmerken van de situatie bepalen het gedrag van mensen in organisaties. Met andere woorden, het maakt niet veel uit of een bepaalde positie 
ingevuld wordt door persoon $X$ dan wel $Y$. In psychologische bewoordingen, functies in organisaties kunnen beschouwd worden als sterke situaties. Jeffrey Pfeffer (Davis-Blake en Pfeffer, 1989: 387), een prominente organisatiewetenschapper, drukt het als volgt uit:

"... because most organizational settings are strong situations, individual dispositions are likely to have only limited effects on reactions in organizations".

Gegeven deze bewering, heeft het dan nog wel zin om de effecten van de persoonlijkheid van mensen in organisaties te bestuderen? Mijn antwoord is volmondig ja. Ten eerste betwist ik dat de meeste situaties in organisaties als sterk kunnen beschouwd worden. De omgeving waarin mensen opereren in organisaties is dikwijls wel zodanig ambigue dat het helemaal niet duidelijk is welk gedrag wenselijk is. Het is bijwoorbeeld helder dat orgamisatietransformaties, structurele en culturele veranderingen en strategische besluitvorming situaties zijn die instabiliteit en onzekerheid met zich meebrengen en ruimte laten voor diversiteit in reacties en gedrag (House et all, 1996). Het komt er met andere woorden op aan de effecten van persoonlijkheid te bestuderen in relevante situaties. Merk op dat zelfs indien de meeste organisatiesituaties sterk zouden zijn, mensem nog steeds kunnen verschillen in de wijze waarop ze psychologisch reageren op verschillende situaties (House et al., 1996).

Ten tweede is het ook duidelijk dat het uiteindelijk een empirische kwestie is of verschillen tussen mensen in organisaties van belang zijn. Hoewel binnen de arbeids- en organisatiepsychologie (Organizational behavior in de Angelsaksische wereld) verschillende bijdragen op dit domein geteverd werden, speelt het empirisch onderzoek naar persoonlijkheid in de organisatiewetenschappen, zoals eerder vermeld, een secundaire rol (Weiss en Adler, 1984). Dit heeft echter niet alleen te maken met de hantering van een overwegend sociologisch mensbeeld, maar ook met de ronduit gebrekkige kwaliteit van een groot deel van het bestaande onderzoek naar de effecten van persoonlijkheid. De onvermijdelijk teleurstellende resultaten van dit onderzoek hebben verschillende 
organisatiewetenschappers onterecht doen besluiten dat persoonligkheidskenmerken er niet toe doen en hebben de dominantie van het situationeel determinisme nog versterkt.

Wat is er dan mis met bestaand onderzoek? Drie methodologische tekortkorningen zijn het vermelden waard. Een eerste probleem is dat onderzoekers onvoldoende onderscheid maken tussen sterke en zwakke situaties. Persoonlijkheid kan slechts invloed hebben op het gedrag wanneer mensen keuzemogelijkheden hebben. In situaties zonder vrijheidsgraden schrijven de omstandigheden als het ware voor welk gedrag gewenst is. Ik ben ervan overtuigd dat vele non-findings het gevolg zijn van de bestudering van de effecten van persoonlijkheid in sterke situaties (zie ook Schneider, 1987). Een tweede probleem is dat onderzoekers al te vaak persoonlijkheidskenmerken aanwenden om specifiek gedrag in een specifieke situatie te voorspellen. Persoonlijkheidskenmerken zijn echter algemene trekken van mensen en verklaren daarom ook vooral algemene gedragstendensen, geaggregeerd over situaties en tijd (Buss, 1989). Een laatste probleem is dat vele onderzoekers een off-the-shelff methode gebruiken met betrekking tot persoonlijkheidsonderzoek (House et al., 1996: 220). Deze werkwijze gaat als wolgt. Men onderzoekt effecten van situaties op het gedrag van mensen. Men neemt verwolgens willekeurig een persoonlijkheidstest van het schap en voegt die toe aan de vragenlijst als een appendix in de hoop hiermee een deel van de niet verklaarde variantie te kunnen verklaren. Het is duidelijk dat zulk een a-theoretische benadering weinig interessante resultaten kan opleveren. Ik sluit mij dan ook aan bij Weiss en Adler (1984: 41) die pleiten:

"... against the continued treatment of personality as ad hoc, scattered, shotgun attempts to predict behavior or as appendages to existing research designs".

Als men zinvolle inzichten wil bekomen dan is het essentieel dat persoonlijkheid een centrale plaats in het anderzoeksmodel inneemt. De afstand tussen persoonlijkheid en gedrag is groot. Onderzoekers moeten daarom duidelijk de theoretische, tussentiggende effecten van verschillende 
persoonlijkheidskenmerken expliciteren. Slechts dan is een doordachte keuze van persoonlijkheidskenmerken en van situaties waarin deze kenmerken relevant zijn, mogelijk.

\section{PERSOONLIJKHEID EN GEDRAG IN EEN ECONOMISCHE CONTEXT}

Hopelijk ben ik er ondertussen in geslaagd u te overtuigen van het feit dat mensen fundamenteel verschillen van elkaar. Ik heb ook uiteengezet dat de consequenties hiervan in de economische wetenschappen niet en in de organisatiewetenschappen inadequaat onderzocht zijn. In het vervolg van mijn oratie wil ik aaritonen dat fundamentele variatie tussen mensen nochtans belangrijke implicaties heeft voor het begrijpen van gedrag in een economische context. Met behulp van eigen onderzoek zal ik dit illustreren.

De persoonlijkheid van mensen kan op zeer uiteenlopende wijzen in kaart gebracht worden. In mijn onderzoek heb ik echter, on redenen die ik later zal uiteenzetten, hoofdzakelijk de aandacht gevestigd op êen persoonlijkheidskenmerk, met mame locus van controle. Het begrip locus van controle vindt zijn oorsprong in de sociale leertheorie van Rotter (1966). Deze auteur heeft aangetoond dat mensen fundamenteel verschillen met betrekking tot de mate waarin zij menen de gebeurtenissen in hun leven te kunnen beheersen. Personen met een eerder externe locus van controle, kortweg externen, zien zichzelf als relatief passieve agenten en menen dat de gebeurtenissen in hun leven het gevolg zijn van oncontroleerbare krachten. Zij geloven dat hetgeen zij wensen te bereiken het gevolg is van geluk, toeval of machtige personen en instituties. Mensen met een eerder interne locus van controle, kortweg internen, daarentegen beschouwen zich als actieve agenten, voelen zich meester van hun lot en hebben vertrouwen in hun mogelijkheden om de omgeving te beinvloeden. Zij menen dat ze door eigen inspanningen en vaardigheden de gebeurtemissen in hun leven bepalen. De locus van controle kan op een betrouwbare 
manier gemeten worden met een standaard vragenlijst ontworpen door Rotter (1966), welke door ons in het Nederlands werd vertaald.

De keuze van dit concept voor de studie van de implicaties van persoonlijkheidsverschillen in een economische context steunt op twee gronden. Ten eerste theeft locus van controle te maken met diepgewortelde verschillen tussen mensen. Recent onderzoek toont namelijk aan dat de locus van controle een erfelijke basis heeft (Miller en Rose, 1982; Pedersen et al., 1989). Gelijklopend hiermee zijn de bevindingen waaruit blijkt dat deze eigenschap samenhangt met belangrijke verschillen in psychofysiolagische reacties die te verklaren zijn door een relatief sterkere activatie van de rechterhersenhelft ten opzichte van de linkerhemisfeer bij extemen en een activatie-overwicht in de linkerhemisfeer bij internen (De Brabander et aL., 1992). Ten tweede toont overwloedig onderzoek aan datt de locus van controle samenhangt met gedragsaspecten die uitemate relevant zijn voor effectief functioneren in een economische context. Samengevat komt het erop neer dat internen beschikken over een groter leer- en aanpassingsvermogen dan externen en dat ze duidelijk doelgerichter en stressbestendiger zijn (voor een samenvatting zie Lefcourt, 1982; van Olffen, 1999). Het belang van deze verschillen in vaardigheden zal $3 k$ kort illustreren met behulp van onderzoek in drie belangrijke bedrijfseconomische domeinen, met name coöperatie, het succes van ondernemingen en het functioneren van teams.

\section{Illustratie 1: Locus van controle en coöperatie.}

Van oudsher trachten sociale wetenschappers inzicht te krijgen in het spanningsveld tussen coöperatief versus niet-coöperatief gedrag. Binnen dit domein wordt bijzonder veel experimenteel onderzoek verricht om inzicht te krijgen in de factoren die coöperatie bevorderen (Pruitt en Kimmel, 1977). Het gevangenendilemma en andere zogenaamde mixed-motive games vormen hierbij doorgaans de experimentele context omdat deze spellen toelaten op een eenvoudige wijze coöperatief versus competitief gedrag te modelleren. Het overgrote deel van dit experimenteel onderzoek heeft vooral de effecten bestudieerd van externe omstan- 
digheden, zoals marktvorm, op het niveaus wan coöperatie (voor een uitzondering zie Kuhimann en Marshello, 1975). Wij gebruikten ook een gevangenendilemma in ons onderzoek maar deze keer om de effecten wan individuele verschillen, met name locus van controle, op de mate van coöperatief gedrag te bestuderen (Boone en van Witteloostuijn, 1999; Boone et al., 1999a, 1999b).

Veertig studenten van de Uniwersiteit Maastricht speelden het gevangenendilemma in vijf varianten, waarbij de spelomgeving van variant tot. variant verandert. Wat zijn de belangrijkste bevindingen? Internen blijken zich gemiddeld coöperatiever te gedragen dan externen ongeacht de spelomstandigheden. Men kan hieruit echter geenszins besluiten dat internen vredelievender zouden zijn dan externen. Dit wordt duidelijk wanneer we naar het patroon van keuzen kijken over alle ronden van de verschillende spelvarianten heen. Het gedrag van internen vertoont een herkenbaar patroon waarbij coöperatief en competitief gedragl om strategische en instrumentele redenen worden afgewisseld. Het is een strategie gericht op het beheersen van het gedrag van de tegenspeler om thet gewenste doel, in dit. geval winst, te bereiken. Men kan het vergelijken met het gedrag van een visser die met behulp van aas de vis lokt om vervolgens toe te slaan. Het eindresultat van die strategie is dan ook dat de (fictieve) totale winst van internen maar liefst $60 \%$ hoger ligt dan de cumulatieve winst behaald door externen. Uit dit onderzoek komt het volgens mij wezenlijke verschil tussen internen en externen goed tot uiting: de mate waarin gedrag doeigericht en strategisch aangewend wordt am gewenste uitkomsten te behalen.

Illustratie 2: Locus van controle en ondernemingsresultaten.

Om het belang van persoonlijkheid een tweede maal te illustreren wil ik een sprong maken van het laboratorium naar de echte wereld, die van het topmanagement. In de bedrijfswereld gaat men ervan uit dat de persoon van de topmanager uitermate belangrijk is voor de wijze van functioneren en de resultaten van ondernemingen. Dit blijkt bijvoorbeeld uit de standaardoplossing die aangewend wordt wanneer het slecht gaat met een 
onderneming: men geeft de manager die verantwoordelijk wordt geacht voor de vertiezen een gouden handdruk, men selecteent een nieuwe marager die met grote trom wordt ingehaald en klaar is kees. Merk op dat hetzelfde fenomeen ook schering en inslag is in de sportwereld. Dit gebruik steunt impliciet op drie cruciale assumpties: 1) managers verschillen met betrekking tot vaardigheden en inzichten ower hoe een organisatie moet geleid worden, 2) deze verschillen hebben uiteindelijk een weerslag op de werking van een organisatie via de implementatie van bijwoorbeeld bepaalde strategieën en/of structuren, en 3) deze organisatieverschillen hebben een beduidende invloed op de ondernemingsresultaten (Hambrick en Mason, 1984).

Vele organisatiewetenschappers menen echter dat deze ketting van redeneringen helemaal niet opgaat. De argumentatie, die geinspireerd is door het eerder geschetste situationeel deterministische mensbeeld, gaat als volgt. Slechts een beperkt aantal welbepaalde individuen zijn geschikt voor het bekleden van topfuncties. Selectieprocessen reduceren bijgevolg de range van verschillen in kenmerken van bedrijfsteiders, zodanig dat het zinloos en bovendien onmogelijk wordt hun invloed empirisch te observeren (Pfeffer, 1977). Zelfs indien topmanagers toch wezenlijk zouden verschillen, dan nog is hun inwloed op de ondernemingsresultaten minimaal. Dit omdat ondernemingen politieke arena's zijn waar collectieve besluitworming de regel is en waar de medewerking van vele anderen moet verkregen worden om specifieke ideeën te implementeren. Met andere woorden, topmanagers zijn ook maar radertjes in een groter geheel en dikwijls ontbreekt het hen aan woldoende macht om de organisatie naar hun hand te zetten (Hannan en Freeman, 1989). Ten slotte beweren velen dat externe factoren, zoals marktomstandigheden en concurrentie, veel belangrijker zijn voor de verklaring van verschillen in ondernemingsresultaten dan factoren die te maken hebben met de interne organisatie (Hannan en Freeman, 1989). Samengevat, men beweert geenszins dat de aanwezigheid van topmanagers onbelangrijk zou zijn. maar wel dat (Weiner en Mahoney. 1981: 45.4): 
"... the particular incumbent of the leadership position is unimportant. ... Organizational and environmental constraints are presumed to limit drastically the influence any leader can exert".

Met andere woorden, het maakt miet uit of de onderneming nu geleid wordt door topmanager $X$ of $Y$.

Tot daar in een notendop een centraal debat in de organisatiewetenschappen tussen wat men aanhangers van de voluntaristische versus deterministische visie is gaan noemen (zie ook Hambrick en Finkelstein, 1987). Aangezien beide partijen hun visie met zinvolle argumentem ondersteunen is het onmogelijk a priori een vaorkeur uit te spreken voor één van beide opvattingen. Dit debat heeft mij dan ook geïnspireerd am een empirisch onderzoek op te starten om uit te zoeken in welke mate en waram de persoonlijkheid van topmanagers invloed uitoefent op de resultaten van ondernemingen (Boone et al., 1996: Boone en De Brabander, 1993; Boone en De Brabander, 1997).

Het onderzoek heeft betrekking op ondernemingen uit de Vlaamse meubelindustrie. Data voor dit onderzoek zijn afkomstig uit verschillende bronnen, met name interviews met en enquêtering van bedrijfsleiders en andere leden van het topmanagementteam en secundaire gegevens zoals jaarverslagen. Afhankelijk van de variabete werd informatie verzameld van een zestigtal ondernemingen. Deze bedrijven stellen gemiddeld 80 personen tewerk.

Wat zijn de belangrijkste bevindingen? In eerste instantie blijkt dat de financiële resultaten van ondernemingen geleid door interne bedrijfsleiders veel hoger zijn dan bedrijven met externe bedrijfsteiders. Dit effect is substantieel: de locus van controle van bedrijfsleiders verklaart ongeveer $20 \%$ van verschillen tussen ondernemingen in rentabiliteit en productiviteit. Vervolgens hebben we gespeurd naar de oorzaken van dit verschil. Met name, waarom doen interne bedrijfsleiders thet beter dan externe bedrijfsleiders? Uit het onderzoek blijkt dat de reden miet zozeer gezocht moet worden in verschillen in de inhoud van de gevoerde ondernemings- 
strategie. Het is bijwoorbeeld niet zo dat interne bedrijfsleiders betere strategische keuzen maken, in tegendeel. Het blijkt namelijk dat interne bedrijfsleiders meer geneigd zijn een innovatiegerichte strategie te voeren, een strategie die in deze bedrijfstak niet rendabel is. Alles wijst erop dat interne bedrijfsleiders effectiever zijn in de implementatie van hun strategische keuzen. Het maakt daarom voor interne bedrijfsteiders niet echt uit welke strategie ze voeren.

Een tekortkoming van dit onderzoek is dat locus van controle en ondernemingsresultaten op hetzelfde tijdstip gemeten worden. Sommige auteurs maken zich met name zorgen dat goede ondernemingsresultaten wel eens de oorzaak zouden kunnen zijn van een interne locus van controle in plaats van omgekeerd. De redenering is dat goede resultaten het zelfvertrouwen van mensen verhoogt en daarom de ontwikkeling van een interne locus van controle faciliteert. Gegeven het fundamentele karakter van verschillen in locus van controle, zoals eerder vermeld, lijkt me dit onwaarschijnlijk. Om op deze kwestie echter meer licht te werpen hebben we een vervolgonderzoek opgestart waarbij het lot van iedere onderneming tot zeven jaar na de datum van het oorspronkelijke onderzoek in kaart gebracht werd. De bedoeling was om na te gaan of de locus van controle score gemeten in 1991 toelaat te voorspellen welke ondernemingen mog overleven in 1997. Van de 61 bestudeerde ondernemingen bleken er ondertussen 23 procent bankroet. Van deze gefalcce ondernemingen was er slechts één die in 1991 geteid werd door een interne bedrijfsleider. De eerder externe bedrijfsleiders nemen alle andere falingen, met name 13, voor hun rekening. Dit opmerkelijke resultaat blijft staan zelfs na controle voor andere potentiële determinanten van faling (Boone et al., 2000). We kunnen hieruit besluiten dat de locus van controle van topmanagers een belangrijke voorspeller is van de prestaties van kleine ondernemingen zowel op korte als op lange termijn. Of individuele topmanagers een (even) belangrijke determinant zijn van de prestaties van grote ondernemingen blijft een open vraag en vergt nader onderzoek. In ieder geval ligt het voor de hand om in dat geval niet alleen te kijken naar de bedrijfsleider, maar naar het hele topmanagementteam. 
Illustratie 3: Psychologische samenstelling van teams en ondernemingsresultaten.

Het is duidelijk dat topmanagers in de meeste ondernemingen niet alleen werken maar wel bestissingen nemen en verantwoordelijkheden delen in teamverband. Het functioneren van topmanagement- en ander teams in organisaties is op dit ogenblik een hot topic in zowel de academische als de populaire managementliteratuur. Overal hoort men dat ondernemingen er goed aan doen om mensen met verschillende persoonlijkheidskenmerken samen te brengen in teams. Met andere woorden, diversiteit is thet sleutelwoord (voor een genuanceerde benadering van diversiteit zie Milliken en Martins, 1996). Dit advies is op zijn minst voorbarig want er bestaat nauwelijks onderzoek over de effecten van de psychologische samenstelling op het functioneren van teams (zie van Olffen, 1999). Om dit hiaat enigszins op te vullen, hebben we een onderzoek bedacht waarin we expliciet nagaan wat er gebeurt wanneer managers met een verschitlende perceptie van controle samengebracht worden om te werken aan een complexe taak. Deze studie is tevens onze derde illustratie van het belang van persoonlijkheid maar dan in een teamcontext. De vraagstelling is: welke managementteams behalen de beste ondernemingsresultaten en waarom (zie Boone et al., 1998)?

Om één en ander zo gecontroleerd mogelijk te bestuderen, hebben we besloten om in eerste instantie een experimentele studie uit te voeren. De managementteams in deze studie bestaan uit deelnemers aan een grootschalig Europees management game. Het spel dat door ondernemingen gebruikt wordt als onderdeel van de opleiding van jonge managers, is een realistische simulatie van een ondernemingsomgeving waarbij de marktontwikkeling bepaald wordt door zowel exogene krachten als endogene factoren. De teams moeten beslissingen formuleren op alle belangrijke functionele besluitvormingsdomeinen, zoals productie, marketing, financiering, personeel en R\&D. De teams concurreren in groepen van vijf, het equivalent van een bedrijfstak, in drie markten met drie verschillende producten en dit over verschillende ronden. 
58 teams namen deel aan het onderzoek. We hebben een onderscheid gemakt tussen drie generieke teamtypes: teams met overwegend interne leden, teams met overwegend externe leden en gemengde of heterogene teams bestaande uit zowel interne als externe leden. We nelden nog dat een onderscheid gemaakt werd tussen stabiele en dynamische bedrijfstakken. Dynamische bedrifstakken worden gekenmerkt door relatief onvoorspelbare fluctuaties in het prijsniveau en de marktaandelen.

De resultaten leren ons dat de rentabiliteit behaald door interne teams gemiddeld 70 procent hoger is dan die van het tweede-beste teamtype, met name externe teams. De verschillen tussen de teamtypes bijken vooral uitgesproken te zijn in dynamische bedrijfstakken. De gemiddelde rentabiliteit van interne teams is 7 procent hoger dan externe teams (het tweede-beste teamtype) in stabiele bedrijfstakken. In dynamische bedrijfstakken neemt dit werschil toe tot een indrukwekkende 154 procent. Een belangrijke vaststelling is dat gemengde teams het uitermate stecht doen, vooral in dynamische bedrijfstakken. De rentabiliteit van gemengde teams wordt zelfs negatief in dynamische bedrijfstakken.

Uit deze studie blijkt duidelijk dat diversiteit met betrekking tot locus van controle niet werkt. Dit is waarschijnlijk een verrassing voor het groeiend aantal onderzoekers die menen dat diversiteit van managementteams een essentieel instrument is om het aanpassingsvermogen van organisaties in dynamische omgevingen te vergroten. Onze resultaten suggereren dat de negatieve effecten van diversiteit niet onderschat mogen worden. Diversiteit kan namelijk de efficièntie van de taakuitwoering in teams belemmeren omdat veel tijd en energie moet besteed worden in de overbrugging van communicatie barrières en conflicten (McCain et al.. 1983; Boone et. al., 1998).

\section{ROUND-UP EN VERVOLGONDERZOEK}

Uit de voorgande illustraties blijkt overduidelijk dat verschillen tussen mensen, in samenhang met verschillen in situaties waarin mensen zich 
gedragen, varn belang zijn om economische fenomenen te begrijpen. Meer nog, met behulp van één persoontijkheidskenmerk kon in elk van de studies een substantieel deel van de variantie verklaard worden binnen drie centrate thema's in de organisatiewetenschappen, met name samenwerking, teamfunctioneren, tot en met het succes en owerleven van organisaties. Dit opmerketijke resultaat is mede te danken aan het feit dat systematisch gepoogd werd om de drie tekortkomingen wan vorig persoonlijkheidsonderzoek in de orgamisatiewetenschappen, zoals beschreven in de inleiding van mijn oratie, te vermijden. Ten eerste hadden we telkens a priori goede theoretische redenen om het persoonlijkheidskenmerk locus wan controle als verklarende variabele in het onderzoek te betrekken. Enkel wanneer men de gedragsconsequenties van een persoonlijkheidskenmerk grondig kent, kan men theoretisch gefundeerde verwachtingen formuLeren en zinvolle verbanden traceren. Ten tweede hebben we telkens bewust gekozen om het gedrag van mensen te bestuderen in die situaties die ruimte laten voor diversiteit in keuzen en gedrag. Het is bijwoorbeeld duidelijk dat de omstandigheden waarin bedrijfsleiders en managementteams opereren niet als sterk kunnen beschouwd worden, maar daarentegen veel vrijheid van handelen toelaten. Ten derde hebben we steeds gepoogd tendensen en patronen in het gedrag van mensen te achterhalen. Algemene persoonlijkheidskenmerken zijn niet geschikt om gedrag te voorspellen in een specifieke situatie. Daarom werd bijvoorbeeld in het gevangenendilemma gedrag geobserveerd in verschillende varianten van het spel en in het managementteamspel over verschillende ronden. De conclusie is helder: als persoonlijkheidsonderzoek adequaat wordt uitgevoerd zijn de effecten van verschillen tussen mensen substantieel. Men kan daarom onmogelijk volhouden dat de dispositionele benadering in de organisatiewetenschappen niet meer is dan een luchtspiegeling, zoals Davis-Blake en Pfeffer beweren (Davis-Blake en Pfeffer, 1989). De feiten weerleggen dit. of zoals House et al. (1996: 203) het formuleren:

\section{"Rumors of the death of dispositional research are vastly exaggerated":}

Hoe moet het nu verder met dit soort onderzoek? Ons inziens is het heel belangrijk om de effecten van menselijke variatie te bestuderen in een 
meer dyramische context dan voorheen om de heel eenvoudige reden dat men er niet wanuit kan gaan dat de kenmerken van mensen toevalthg verdeeld zijn over werschillende situaties (Schneider, 1987). Zo heeft bijwoorbeeld niet iedereen de vaardigheden om het tot topmanager te schoppen. Het gevolg is dat mensen die daar terechtkomen en succesvol zijn verschillen wan andere mensen en dat de groep van topmanagers wat kenmerken betreft relatief homogeen zal zijn. Uit een onderzoek naar het carrièreverloop wan economie-alumni van de Universiteit Antwerpen blijkt inderdaad dat intemen een grotere kans hebben om topmanager te worden dan extemen, vooral in dynamische bedrijfstakken war de vaar digheden wan internen heel belangrijk zijn (De Brabander et at., 1999). De werking van dit soort selectieprocessen heeft tot gevolg dat men in een welbepaalde omgeving slechts een beperkt deel van de variatie van verschillen tussen mensen kan observeren. Dit heeft twee belangrijke implicaties. Ten eerste treedt hierdoor in statisch onderzoek wat men in de statistiek restrictie in rang noemt op, hetgeen de kans op het winden van significante resultaten aanzienlijk reduceert. Het is namelijk moeilijk om effecten van werschillen tussen mensen te traceren wanneer de verschillen a priori klein zijn. Als men ze desalniettemin vindt, pleit dit dus sterk woor de kracht van het effect en het belang van de bevinding. Dus, restrictie in rang maakt de resultaten van het hierboven beschreven onderzoek nog opmerkelijker. Ten tweede, door enkel te kijken naar het effect van verschillen tussen mensen in éen welbepaalde omgeving mist men een heel belangrijk deel van de wisselwerking tussen deze verschillen en de kenmerken en het functioneren van sociale systemen. Dit soort onderzoek leert ons met hame weinig over waarom precies omgevingen verschillen in de eerste plaats en de rol die menselijke variatie hierin speett.

Inzicht hierin kan slecht verkregen worden door het analyseniveau van het indiwidu te verlaten en te kijken naar werschillen tussen socialle systemen, bijwoorbeeld organisaties en groepen, in termen van de geaggregeerde kenmerken van de leden van het systeem. Benjamin Schneider heeft een interessante theorie ontwikkeld om deze dynamiek tussen menselijke variatie, en structuren en processen van sociale systemen op 
een hoger aggregatieniveau te bestuderen (Schneider, 1987). Schneider gat er vanut dat mensen collectief hun omgeving creeren door wat hij de cyclus van aantrekking, selectie en verloop [Attraction-Selection-Attrition (ASA) cyclus] noent. In een organisatiecontext betekent dit dat mensen zich aangetrokken voelen tot, geselecteerd worden door en uiteindelijk blijwen in organisaties die passen bij hun specifieke kenmerken en vaardigheden. Schneider et al. (1998: 463) specificeren de cyclus als volgt:

"The ASA cycle suggests that, first, people are differentiolly attracted to organizations on the basis of an organization's character and the character's manifestations in organizational structure, strategy, and culture. This proposition is consistent with research in vocational psychalogy and with the literature on organizational choice... Second. through formal and informal selection strategies, organizations choose those individuals who are compatible with the working environment or who fit the character of the organization ... The hypothesized basis of the selection stage in the ASA model is not a new conceptualization. Barnard (1938) prescribed selecting and promoting people to executive positions who match those already in place... People who do not fit a working environment tend to leave or must be relieved. The literature on tumover has consistently supported this hypothesis".

Deze ASA cyclus heeft tot gevolg dat het sociale systeem zichzelf reproduceert (Kanter, 1977) en in stand houdt. Meer nog, deze processen reduceren de menselijke variatie binnen organisaties. Het uiteindelijke resultaat is dat de wijze waarop organisaties functioneren onlosmakelijk verbonden is met de attributen van de personen die deel uitmaken van die organisatie (Schneider, 1987). De organisatie heeft als het ware de neiging een modale persoonlijkheid te ontwikkelen in functie van de kenmerken van haar leden. Recent empirisch onderzoek ondersteunt inderdaad deze centrale propositie van het ASA model (Schaubroeck et aL., 1998; Schneider et al. 1998). Zo gebruikten Schneider et al. (1998) de Myers-Briggs indicator om de cognitieve persoonlijkheid van 13,000 managers uit 142 organisaties te achterhalen. Zij vinden dat tot 25 procent van de variantie in de persoonlijkheid van deze managers kan 
verklaard worden door het feit dat ze in verschillende organisaties werken. Dit resultaat illustreert duidelijk dat de persoonlijkheid van mensen niet random verdeeld is over situaties. Menselijke variatie kan dus niet als ruis beschouwd worden zoals zo vak impliciet of expliciet wordt aangenomen.

Hoewel deze feiten de validiteit van het ASA model onderstrepen, bliven vele vragen nog steeds onbeantwoord: welke mensen voelen zich aarigetrokken tot welke organisaties en waarom, wat bepaalt de keuze van selectieprocessen in verschillende organisaties, op welke kenmerken wordt er geselecteerd en waarom, waarom thebben mensen de neiging om mensen te selecteren die op hen lijken, wie verlaat er vrijwillig of onvrijwillig een organisatie, en wat zijn de gevolgen van deze processen op het functioneren en de resultaten van ondernemingen? Slechts door systematisch onderzoek naar deze deelvragen op te zetten kunnen we ten volle de rol van menselijke variatie in het functioneren van sociale systemen begrijpen. Deze benadering werpt bovendien een vermieuwende kijk op êén van de meest fundamentele vragen in de arganisatiewetenschappen, met name hoe komt het dat er zoveel verschillende soorter van organisaties bestaan (Hannan en Freeman, 1977). Ten slotte is het duidelijk dat zulk soort onderzoek het patentieel heeft om een brug te slaan over de steeds groter wordende kloof tussen het micro- en macrodeel van de organisatiewetenschappen (Carroll en Harrison, 1998).

\section{MISVATTINGEN EN IMPLICATIES}

In het eerste deel van deze oratie citeerde ik onderzoek welke schattingen rapporteert over de mate waarin persoonlijkheid erfelijk bepaald is. Het is wan groot belang op het einde van mijh oratie hierop terug te komen omdat deze schattingen, die gebaseerd zijin op zogenaamde erfelikheidscoefficienten, dikwijls totaal verkeerd geinterpireteerd worden. Erfelijkheidscoêfficiënten geven namelijk informatie over de bron van verschillen tussen individuen - genetisch of omgeving - in een bepaalde populatie maar geven geen informatie over het absolute niveau 
van competentie warrond deze variatie optreedt (Bronfenbrenner en Ceci, 1994). Rose et aL (1990: 116) stellen het als wolgt:

"The heritability of a trait only gives information about how much genetic and environmental variation exists in the population in the current sets of environments".

In het geval van intelligentie bijvoorbeeld vindt men doorgaans dat ongeveer 70 procent van de verschillen tussen mensen toegeschreven kan worden aan genetische variatie (Bouchard et al., 1990). Dit betekent geenszins dat de opwoeding en de omgeving warin mensen opgroeien geen invloed hebben. Mark Twain heeft ooit eens in een gedachte-experiment voorgesteld om kinderen tot 12 jaar op te laten groeien in tonnen en hen te voeden door een gat in de wand van de ton. Het is duidelijk dat het IO wan deze kinderen gemiddeld veel lager zal zijn dan dat van kinderen opgegroeid in normale omstandigheden. Dus de omgeving heeft een belangrijke invloed op de gemiddelde IQ-score. Nochtans: zou een erfelijkheidscoëfficient berekend op de IQ-scores van deze kinderen aangeven dat de verschillen voor 100 procent een genetische oorsprong hebben. Het geschatte effect van de omgeving op de verschillen in IQ-scores zal in dit voorbeeld mamelijk nul zijn omdat alle kinderen in een gelijkaardige ton opgroeiden. De erfelijkheidsschattingen kunnen daarom slechts geïnterpreteerd worden als een indicatie van de bron van verschillen tussen mensen die in een wellbepaalde set van omgevingen opgegroeid zijn (Bronfenbrenner en Ceci, 1994). Het spreekt voor zich dat de IQ-erfelijkheidsschattingen die in de literatuur gerapporteerd worden betrekking hebben op mensen die in normale omstandigheden opgevoed werden.

Verder is het opvallend dat dikwijls verkeerde conclusies gekoppeld worden aan de geaccumuleerde bevindingen in het domein van de gedragsgenetica. Genetisch gedetermineerde verschillen impliceren geenszins determinisme noch fatalisme wat opvoeding en sociale politiek betreft. Wat opvoeding betreft, komt het er op aan kinderen die omgeving aan te bieden waarin het genetisch potentieel maximaal aan bod kan 
komen. Het aambieden van deze zogenaamde proxinial processes speelt namelijk een cruciale rol in de bepaling van welke individuele vaardigheden gerealiseerd worden en in welke mate. Dit is misschien wel dé belangrijkste taak van ouders en opvoeders: mogelijkheden en steun aanreiken waardoor de ingeboren capaciteiten van kinderen tot volle wasdom kunnen komen. Het is niet nature or murture, zelfs niet nature and nurture, maar nature through nurture (Scarr en McCartney, 1983; Bouchard et al., 1990).

Wat sociale politiek betreft, worden de resultaten van dit soort onderzoek niet alleen verkeerd geïnterpreteerd maar jammer genoeg ook gevaarlijk misbruikt voor politieke doeleinden. Erfelijkheid wordt met name ingeroepen om extreem liberalisme en een laisser faire politiek te legitimeren: sommige mensen zouden met name niet in de wieg gelegd zijn voor maatschappelijk succes. Het kan echter niet genoeg benadrukt worden dat onderzoeksresultaten over de bron van verschillen tussen mensen op geen enkele wijze een anti-sociale politiek voorschrijven (Goldberger en Manski, 1995). Wel integendeel. Een samenteving waarin het belang van erfelijkheid erkend wordt heeft nood aan een actieve sociale politiek die aan iedereen optimale kansen tot ontplooiing biedt. Omdat zulk een politiek tot doel heeft de beperkende, negatieve effecten

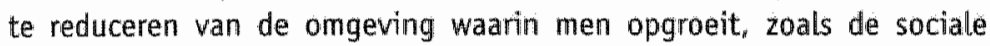
klasse, op de ontwikkeling van mensen, is het resultaat paradoxaal genoeg een samenteving waarin juist de bijdrage van erfelijkheid als bron van verschillen maximaal is (Bronfenbrenner en Ceci, 1994). Lloyd Humphreys (1991: 343), een prominent wetenschiapper op het gebied van vaardigheden, beschrijft het als volgt:

"A society can deal effectively and democratically with genetic contributions to individual differences in abilities and temperaments with policies designed to maximize the achievement of each citizen without regard to sex, race, ethnicity, or social status. This requires a focus on equality of opportumity. This goal with this focus is equivalent to the goal of maximizing heritability of the human qualities that produce high levels of achievement". 
Wat ook de bron van menselyke verschillen is, een ding stadt wast: mensen veranderen nauwelijks vanaf hun volwassenheid. We hebben meer dan een eeuw onderzoek nodig gehad om bevestigd te zien wat, William James (1890/1981: 125-126), een wan de grondleggers van de wetenschappelijke psychologie, reeds in 1890 zo eloquent opmerkte:

"Already at the age of twenty-five you see the professional mannerism settling down on the young commercial traveller, on the young doctor, on the young minister, on the young counsellor-at-law. You see the little lines of clevage runming through the character, the tricks of thought, the prejudices, the ways of the "shop", in a word, from which whe man can by-and-by no more escape than his coat sleeve can suddenly fall into a new set of folds... In most of us, by the age of thirty, the character has set like plaster, and will never soften again".

Stabiliteit van persoonlijkheid impliceert niet noodzakelijk dat mensen niet kunnen weranderen (Costa en Mccrae, 1993). De feiten leren ons echter well dat het optimisme van zij die geloven dat leren de snelweg is naar menselijke perfectie op zijn minst overdreven is (Hill, 1997). Hoewel th geloof in de maakbaarheid van de samenteving, zijn er duidelijk grenzen aaln de maakbaarheid van mensen. Deze vaststelling heeft naast de hierboven gemelde consequenties voor opvoeding en sociaal beleid ook belangrijke implicaties voor de wijze waarop organisaties functioneren. Vele organisaties voeren namelijk een personeelsbeleid dat op twee peilers steunt die jammer genoeg geen rekening houden met de menselijke aard. Ten eerste worden werknemers meestal als eenheidsworst beschouwd waarop passe porttout managementpraktijken van toepassing zijn. Wat goed is voor eên werknemer is gloed voor alle werknemers. Ten tweede gaat men uit van de grenzeloze kneedbaarheid van het personeel. Flexibiliteit van mensen is het toverwoord: hedereen moet alles kunnen. Als een personeelslid niet geboren iis als een schaap met vijf poten, dan makt men er wel éen van.

Ik denk echter dat het noodzakelijk is dat organisaties meer rekening houden met de intrinsieke talenten en vaardigheden van mensen. Mensen 
renderen slechts en zijn intrinsiek gemotiveerd wanneer er een goede match tot stand gebracht wordt tussen enerzijds het individu en anderzijds de organisatie en de functie. Hier is een cruciale rol weggelegd voor het personeelsbeleid. Het ligt voor de hand dat de implementatie van een nauwkeurig selectie- en mobiliteitsbeleid bijdragt tot de ontwikkeling van zulk een match. Wegens de beperking van de huidige selectietechnieken en -procedures is dit geenszins voldoende. Bowendien worden de kosten van mobiliteit meestal sterk onderschat omdat indirecte kosten ten gevolge van verlies van organisatiekennis (March, 1991) en vermindering van de commitment van de organisatieleden (Pfeffer, 1998; Van Witteloostuijn, 1999) meestal niet meegerekend worden. De uitdaging ligt daarom veeleer in de ontwikkeling van een gedifferentieerd personeelsbeleid waarbij gestreefd wordt naar de optimale ondersteuning en benutting van menselijke variatie in de organisatie. Slechts door structuren te creëren in functie van wat mensen te bieden hebben in plaats van omgekeerd, wordt een halt toegeroepen aan de verkwisting van menselijk kapitaal. Het resultaat is Pareto-optimaal omdat dit niet alleen de productiviteit van de organisaties te goede komt, maar ook het welzijn van mensen.

\section{DANKBETUIGING}

De volgende twee mensen hebben een grote rol gespeeld in mijn wetenschappelijke ontwikkeling. Eerst en vooral Bert De Brabander, hoogteraar psychologie en methodologie aan de Universiteit Antwerpen. Aan mijn beste vriend Bert, die promotor was van mijn proefschriftonderzoek, heb ik heel veel te danken. Van Bert heb ik geleerd hoe je een degelijk onderzoek in elkaar steekt en uitvoert. Tevens heeft hij mijn horizon verruimd door me in te wijden in andere vakgebieden dan het mijne. Vele van de principes die ik nu zelf probeer over te dragen aan studenten en assis. tenten heb ik op mijn beurt van Bert geleerd, zoals het belang van theorie en logica, het betang van het onderbouwen van beweringen met systematische feiten, het belang van het reduceren van een vraagstelling tot zijn essentie en het belang van het combineren van theorieën uit verschil- 
lende disciplines. In Antwerpen liggen dan ook de roots wan mijn huidige aanpak en inzichten. Ik kijk iedere keer opnieuw uit naar de momenten dat we samen onderzoek doen in Antwerpen. Arjen van Wutteloostuijn, hoogleraar international economics and business aan de Rijksuniversiteit Groningen, wens ik ook nadrukkelijk te bedanken voor het vertrouwen, dat me soms zelf ontbreekt, dat hij voortdurend in mij gesteld heeft. Het is Arjen die me in Maastricht een loopbaan aangeboden heeft en me steeds gestimuleerd heeft om de grenzen van mijn kunnen te verkentren. Agien en ik zijn een perfect team omdat we tegebijkertijd complementair zijn (Arjen kan heel goed wat ik minder goed kan en omgekeerd) maar toch op dezelfde golflengte zitten. Wanneer complementariteit gecombineerd wordt met een hechte band dan is diversiteit een zegen. Het feit dat Arjen naar Groningen gaat betekent niet dat onze samenwerking ophoudt. In tegendeel. We hebben onlangs nog een ljist gemaakt van een hele reeks lopende en nog wit te voeren onderzoeksprojecten en daar ben ik heel blij om.

Verder wens ik al mijn collega"s van de faculteit en vooral van de sectie organisatie te danken voor de aangename en stimulerende werkomgeving waarvan ik ondertussen reeds 7 jaar deet uitmaak. In het bijzonder wil ik Ad van Iterson danken wiens wijze raad ik steeds bijzonder waardeer. Ik neem dan ook weinig beslissingen zonder de mening van Ad even gehoord te hebben. Dank ook aan Woody van Olffen en Walter Hendriks voor het enthousiasme waarmee ze de onderzoekslijn die eens begon in Antwerpen mee hebben opgepikt. Het doet goed te weten dat de continuitteit van dit soort onderzoek verzekerd is.

Ik woon in Antwerpen en pendel daarom regelmatig met de auto naar Mastricht. Dit is op zich niet zo leuk ware het niet dat ik regelmatig samen reis met collega Willem Buijink. Willem is zo een nustig en vriende-

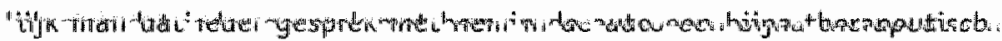
effect heeft. Wat ook prettig is, is dat Willem zoweel weet van zowel wetenschap als het reiten en zeilen van de faculteit dat $\mathrm{ik}$ niet alles zelf hoef te onthouden. Ondertussen heb ik ook een nieuw slachtoffer gevonden om samen te rijden: Allard van Riel. Allard is een filosoof die gespecialiseerd is in de werken van Wittgenstein. Dank zij Allard en onze 
interessante causerieën kan ik nu ook indruk maken door one-liners zoals wowon man nicht sprechen kan, darüber mup man zweigen te droppen tijdens bijvoorbeeld deze oratie.

Tot sllot mijn familie. Bedankt aan mijn ouders en aan de ouders van Dominique voor de steun die ze me altijd geboden hebben. De oratie zou ik willen opdragen aan de grootvaders van onze kinderen die jammer genoeg veel te vroeg gestorven zijn. Van onze drie lieve kinderen, Babette, Louise en Casper heb ik misschien het meeste geleerd. Zij tonen mij iedere keer opnieuw waar ik vandaan kom en wat echt belangrijk is in het leven. Tot slot: Dominique. Je weet wat je voor mij betekent. Bedankt voor de grote rol die je speelt in wie ik ben.

Ik heb gezegd. 


\section{REFERENTIES}

Astley, W.G., en Van de Ven, A.H. (1983)

Central perspectives and debates in organization theory, Administrative science Ouarterly, $28,245-273$.

Barnard, C.I. (1938)

Eunctions of the executive, Cambridge, MA: Harvard University Press. Boone, C, en De Brabander, B. (1993)

Generalized versus specific locus of control expectancies of chief executive officers, Strategic Management Joumal, 14, 619-626.

Boone, C., De Brabandier, B., en Witteloostuijn, A. van (1996)

CEO locus of control and small firm performance: an integrative framework and empirical test, Joumal of Management Studies, 33, 667-699. Boone, C., en De Brabander, B. (1997)

Self-reports and CEO Locus of control research: a note, Organization Studies, $18,949-971$.

Boone, C., Olffen, W. van, en Witteloostuijn, A. van (1998)

Psychological team make-up as a determinant of economic firm performance: an experimental study. Journal of Economic Psychology, 19, $43-73$.

Boone, C., en Witteloostuijn, A. van (1999)

Competitive and opportunistic behavior in a prisoner's dilemma game: experimentat evidence on the impact of culture and education, Scandinavian Journal of Management, te verschijnen.

Boone, C., De Brabander, B., en Witteloosturijn, A. van (1999a)

The impact of personality on behavior in five prisoner's dilemma games, Journal of Economic Pychology, 20, 343-377.

Boone, C., De Brabander, B., en Witteloostuijn, A. van (1999b)

Locus of control and strategic behavior in a prisoner's dilemma game,

Personality and Individual Differences, 27,695-706.

Boone, C., De Brabander, B., en Hellemans, J. (2000)

CEO locus of control and small firm performance: a research note, Organization Studies, te verschijnen. 
Bouchard, T., Lykken, D., McGue, M., Segal, N., en Tellegen, A. (1990) Sources of human psychological differences: the Minessota study of twins reared apart, Science, 250, 223-228.

Bouchard, T. (1994)

Genes, environment, and personality, Science, 264, 1700-1701. Bronfenbremer, U., en Ceci, S.J. (1994)

Wature-nurture reconceptualized in developmental perspective: a bioecological model, Psychological Review, 101, 568-586.

Buss, A.H. (1989)

Personality as traits, American Psychologist November, 1378-1388. Carroll, G.R., en Harison, J.R. (1998)

Organizational demography and culture: insights from formal model and simulation, Administrative Science Quarterly, 43, 637-667.

Costa, P.T., Ir., McCrae, R.R., Zonderman, A.B., Barbano, H.E., Lebowitz, B. en Larson, D.M. (1986)

Cross-sectional studies of personality in a national sample: 2 . Stability in neuroticism, extraversion, and openness, Psychology and Aging, 1 , 144-149.

Costa, P.T., Ir., en McCrae, R.R. (1993)

Set like plaster? Evidence for the stability of adult personality, in T.F. Heatherton en J.L. Weinberger (eds) Can personality change? Washington: American Psychological Association.

Davis-Blake, A., en Pfeffer, J. (1989)

Just a mirage: the search for dispositional effects in organizational research, Academy of Management Review, 14, 385-400.

De Brabander, B., Boone, C., en Gerits, P. (1992)

Lacus of control and cerebral asymmetry, Perceptual and Motor Skills. 75, 131-143.

De Brabander, B., Boone, C., en Witteloostuijn, A. van (1999)

Wie heeft er kans om topmanager te worden?, Niet gepubliceerd manuscript Universiteit van Antwerpen.

Epstein. S. (1979)

The stability of behavior: I. On predicting most of the people much of the time, Journal of Personality and Social Psychology 37, 1097-1126. 
Epstein, S. (1980)

The stability of behavior: $\mathbb{H}$. Implications for psychological research. American Psychologist, 35, 790-806.

Frank, R.H., Gilovich, T., en Regan, D.T. (1993)

Does studying economics inhibit cooperation? Joumal of Economic Perspectives, 7, 159-171.

Funder, D.C., en Colvin, C.R. (1991)

Explorations in behavioral consistency: properties of persons, situations, and behaviors, Joumal of Personality and Social Psychology, 60 . 773-794.

Goldberger, A.S., en Manski, C.F. (1995)

Review article: The Bell Curve, Journal of Economic Literature, 33, 762-776.

Grether, D.M. (1992)

Testing Bayes rule and the representativeness heuristic: some experimental evidence, Joumal of Economic Behavior and Organization, 17, 31-58.

Hambrick, D.C, en Mason, P.A. (1984)

Upper echelons: the organization as a reflection of its topmanagers, Academy of Management Review, 9, 193-206.

Hambrick, D.C., en Finkelstein, S. (1987)

Managerial discretion: a bridge between polar views of organizational outcomes, Research in Organizational Behaviour, 9, 369-406.

Hannan, M.T., en Freeman, J. (1977)

The population ecology of organizations, American Journal of Sociology, 82, 929-964.

Hannan, M.T., en Freeman, J. (1989)

Organizational ecology, Cambridge, MA: Harvard University Press. Harrison, J.R., en Carroll, G.R. (2000)

Modelling culture in organizations: formulation and extension to ecological issues, in A. Lomi en E. Larsen (eds), Simulating organizational societies: theories, models and applications, te verschijnen.

Hill, W.F. (1997)

Learning: a survey of psychological interpretations, New York: Longman. 
Hirshteifer, D., en Rasmusen, E. (1989)

Cooperation in a repeated prisoners' dilemma with ostracism, Joumal of Economic Behavior and Organtization, 12,87-106.

House, R.J., Shane, S.A., en Herold, D.M. (1996)

Rumors of the death of dispositional research are vastly exaggerated. Academy of Management Review. 21, 203-224.

Humphreys, L.J. (1991)

Limited vision in the social sciences. American Joumal of Psychalogy. $104,333-353$.

James, W. (1890/1981)

The principles of psychology (Vol. 1), Cambridge, MA: Harvard University Press.

Kanter, R.M. (1977)

Men and women of the corporation, New York: Basic Books.

Kuhlmann, D.M., en Marshello, A.F. (1975)

Individual differences in game motivation as moderators of preprogrammed strategy effects in prisoner's dilemma, Joumal of Personality. and Social Psychology $32,922-931$.

Lefcourt, H.M. (1982)

Locus of control: current trends in theory and research, Second edition, Hillsdale, New Jersey: Lawrence Erlbaum.

March, J.G., en Simon, H.A. (1958)

Drganizations, New York: John Wiley and Sons. March, J.G. (1991)

Exploration and exploitation in organizational learning, Organization Science $2,71-87$.

Mason, C.F., Phillips, O.R., en Redington, D.B. (1991)

The role of gender in a non-cooperative game, Journal of Economic Behavior and Organization, 15, 215-235.

McCain, B.E., O'Reilly III, C.A., en Pfeffer, J. (1983)

The effects of departmental demography on tumover: the case of a university. Academy of Management Jounal, 26,626-641.

McCrae, R.R. (1993)

Moderated analyses of longitudinal personality stability. Journal of Personality and Social Psychology, 65, 577-585. 
Miller, J.Z, en Rose, R.J. (1982)

Famblial resemblance in locus of control: awin-family study of the internalmexternal scale, Journal of Personality and Social Psychology. $42,535-540$.

Milliken, F.J., en Martins, L.L. (1996)

Searching for common threads: understanding the multiple effects of diversity in organizational groups, Academy of Management Review. 21. $402-433$.

Mischel, W. (1968)

Personality ard assessment. New York: John Wiley and Sons. Mischel, W. (1984)

Convergences and challenges in the search for consistency, American Psychologist, $39,351-364$.

olfen, W. van (1999)

Team level locus of control and competitive team behavior: an experimental study Proefschrift, Maastricht: Datawyse.

Pedersen, N.L., Gatz, M., Plomin, R., Nesselroade, J.R., en McCleam, G.E. (1989)

Individual differences in locus of control during the second half of the life span for identical and fraternal twins reared apart and reared together, Journal of Gerontology, 44, 100-105.

Pervin, L.A. (1985)

Personality: current controversies, issues and directions, Annual Review of Psychology, 36, 83-115.

Pfeffer, J. (1977)

The ambiguity of leadership, Academy of Management Review, 2 , 104-112.

Pfeffer, J. (1997)

New directions for organization theory: problems and prospects, New York: Oxford Uniwersity Press.

Pfeffer, J. (1998)

The human equation: building profits by putting people first, Boston, MA: Harvard Business School Press. 
Prutt, D.p en Kimmel, M. (1977)

Twenty years of experimental gaming: critique, synthesis, and suggestions for the future, Arnual Review of Psychologv $28,363-392$.

Rose, S., Lewontin, R.C., en Kamin, L.J. (1990)

Not in our genes: biology, ideology and human nature Penguin Books. Rotter, J.B. (1966)

Generalized expectancies for internal versus external control of reinforcement, Psychological Monographs, whole number 609.

Scarr, $S_{\text {e }}$ en McCartney, K. (1983)

How people make their own environments: a theory of genoty pe-environment effects, child Development 54, 424-435.

Schaubroek, J., Ganster, D.C., en Jones, J.R. (1998)

Organization and occupational influences in the Attraction-Selection-Attrition process, Journal of Applied Psychology, 83 , 869-891.

Schneider, B. (1987)

The people make the place, Personnel Psychalogy, 40, 437-453.

Schneider, B., Smith, D.B., Taylor, S, en Fleenor, J. (1998)

Personality and organizations: a test of the homogeneity of personality hypothesis, Journal of Applied Psychology, 83, 462-470.

Sörensen, J.B. (1999)

The ecology of organizational demography: managerial tenure distributhons and organizational competition, Unpublished manuscript, University of Chicago.

Tirole, J. (1988)

The theory of industrial organization, Cambridge: MIT Press. Weiner, N., en Mahoney, T.A. (1981)

A model of corporate performance as a function of environmental, organizational, and leadership influences, Academy of Management Journal $24,453 \times 470$.

Weiss, H.M., en Adler, S. (1984)

Personality and organizational behavior, Research in Organizational Bebavior, 6, 1-50. 
Witteloostuijn, A. van (1994)

Lat duizend blomen bloeien: tolerantie in en rond organisaties. Schoonhoven: Academic Service.

Witteloostwin. A. van (1999)

De anorexidstrategie: over de gevolgen van saneren, Amsterdam: De Arbeiderspers. 


\section{MENSELIJKE SOFTWARE VAN BEDRIJFSTAKKEN EN ECONOMIEËN}

\section{REDE}

in verkorte vorm uitgesproken bij het vertrek uit het ambt wan hoogleraar in de bedrijfseconomie en bedrijfskunde, in thet bijzonder marktwerking en ondernemerschap, aan de Faculteit der Economische Wetenschappen en Bedrijfskunde van de Universiteit Maastricht op 10 december 1999

door

\section{Arjen van Witteloostuijn}


. 
Bijna zes jaar geteden heb ik $U$ een minuut lang lastig gevalten met deze muriek.

"Srmells the teen spint" van Nevermind Wirvana, 1991).

Deze keer wilde ik U niet bestoken met dergetijk audiogeweld. Een spreker kan immers ook te veel van zijn gehoor vragen. Het is erg genoeg dat ik $U$ op 39-jarige leeftijd confranteer met een afscheidsrede. De universitaire reglementen vertonen klaarblijkelijk nog altijd mazen in het voorschniftennet. Dat is een jonge instelling als de Universiteit Maastricht te vergeven. Het opbouwen van een fijnmazig en ondoordringbaar stelsel van bureaucratische regelingen en dito procedures vergt inmers eetwen van noeste arbeid. Om de peffectionering van de locale bureaucratie te versnellen kan ik de juridische dienst van de Universiteit Maastricht in ieder geval echter de suggestie voorleggen om met ingang van het volgente millennium te voorzien in een clausule die een afscheutdsrede als die van vandaag eenduidig en $k$ tachtig verbiedt. Met een dergelijke "Clatusule van Witteloostüjn' laat ik ten minste een tastbare erfenis na. Ik wacht in spanning af hoe mijn suggestie wordt verwerkt tot een monument van effectieve en elegante regelgeving.

Het is mij in de afgelopen jaren opgevallen dat formele redes merkwaardig vaak worden getooid met een onbegrifjpelijke titel. Mijn vermoeden is dat menig redenaar naar deze truc grijpt met de bedoeling daarmee in ieder geval wijf spreekminuten te vullen. Omdat ik van deze traditie niet wil afwijken, moet ik beginnen met een titeluitleg. Met de notie van menselijke software worden twee verschillende begrippengroepen onder éen noemer gebracht. ${ }^{1}$ In de economische wetenschappen is het kapitaalbe-

1 Van beide literatuurstromingen is een compact overzicht te vinden in Pennings, J.M., K. Lee \& A. van Witteloostuijn (1998) "Human capital, social capital, and firm dissolution', Academy of Management Joumal 41: 425-440. In deze rede wordt overigens met enige regelmaat schamteloos geciteerd uit eigen werk. 
grip in zwang. Onder verwijzing naar een menselijke drager ervan wordt bínnen de economische wetenschappen nagedacht over de effecten van menselijk, intellectueel en sociaal kapitaal op het functioneren en presteren van economische agenten of entiteiten. Een prominent voorbeeld van deze onderzoektraditie is de theorievorming ter zake het functioneren van arbeidsmarkten. In de (strategisch) managementwetenschappen is de term bron (in jargon: resource) buitengewoon populair. Vanwege het eminente belang wan de homo sapiens in het bedrijfsleven is sinds het begin van de jaren tachtig vooral het vakgebied human resource management tot wasdom gekomen. Het sleutelinzicht van de bronnenbenadering is dat een onderneming haar concurrentiekracht moet ontlenen aan de opbouw en het onderhoud van een unieke en waardevolle bundel van bronnen, inclusief de onmisbare human resources.

Beide begrippen ter zake menseljjke software kunnen worden toegepast op verschillende analyseniveaus. Een individu, een organisatie, een bedrijfstak en een economie zijn onlasmakelijk verbonden met menselijke software. In het vervolg van mijn betoog zal een aantal voorbeelden hiervan de revue passeren. Vooraf is het zinvol drie kenmerken van menselijke software te onderscheiden. Allereerst is het (gemiddelde) niveau van belang: wat is bijvoorbeeld het (gemiddelde) niveau van scholing binnen een bedrij? Daarmaast kan de samenstelling (spreiding) van menselijke software een rol speten: hoe is bijvoorbeeld de leeftijdopbouw van het organisatiepersoneel? Ten slotte kan de geaggregeerde menselijke software additionele eigenschappen vertonen: wat zijn bijvoorbeeld de kenmerken wan het inter-persoonlijke contactennetwerk binnen een onderneming? Deze laatste karakteristiek verdient een nadere concretisering. Met de notie van de additionele kenmerken van geaggregeerde menselijke software kan invulling worden gegeven aan het cultuurbegrip. Vooral de - vaak ongeschreven - regels ter zake menselijke gedragingen en omgangsvormen bepalen de eigenschappen van de cultuur van een organisatie, bedriffstak of economie. In de terminologie van de enige managementgoeroe van Maastrichtse huize - Geert Hofstede ${ }^{2}$ terwijl in

2 Hofstede, 6. (1980) Culture"s Consequences: intemational differences in wark-related values (Beverly Hills, CA: SAGE). 
de ene organisatie, bedrijfstak of economie de angst woor onzekerheid en een voorliefde voor hierarchie de toon zetten, wordt het menselijke verkeer in de andere orgamisatie, bedrijfstak of economie gedomineerd door tolerantie woor onzekerheid en afkeer van autoriteit.

Waarover ik het vandaag niet wil hebben, is de rol van mensen in organisaties. Daarover heeft mijn collega Christophe Boone immers ongeveer een half uur lang prachtig gesproken. ${ }^{3}$ Natuurlijk is de homo sapiens onmisbaar binnen organisaties. Helaas kan het intrappen van deze open deur geen kwaad in de jachtige wereld van het mondiale bedrijfsteven. Immers: de waak mensonterende saneerdrift in het grootbedrijf lijkt te zijn gekomen om te blijven. De hete herfst van 1999 heeft ook in polderwonder Nederland weer een groot aantal voorbeelden opgeleverd van de moderne machomanagementstijl van leiderschap: AKZO Nobel sluit de verffabriek in Sneek. Philips verkast de spaarlampenproductie van Terneuzen naar Polen, Corus heeft aangekondigd dat de zware-stalenproductie in IJmuiden moet worden afgebouwd, enzovoort. Ook in Limburg heeft het saneervirus weer ouderwets toegesilagen: bij DSM moet het met duizend werknemers minder kunnen en NedCar gaat ten minste vijfhonderd uitzendkrachten naar huis sturen. In de polderwonderjaren negentig is de nieuwswaarde van dergelijke berichten gering. De beurs reageert enthousiast, het personeel is teleurgesteld en de vakbonden pleiten voor eem vriendelijk sociaal plan. Daarna is het tijd om over te gaan tot de orde wan de volgende dag.

Wanneer Chriistophe Boone gelijk heeft - en wie durft daaraan te twijfelen? - dan worden de positieve korte-termijneffecten van deze en andere reorganisatiemaatregelen binnen afzienbare tijd overvleugeld door de lange-termijnschaduwzijden. Van herstructureringen, reorganisaties en saneringen kan immers veel worden gezegd, maar niet dat zij een positieve bijdrage leveren aan de kwaliteit en kwantiteit van de investeringen in het personeel. De bevindingen van een wassende stroom onder-

3 Henseljke hardware van homindwen en orgamisaties (1999), rede uitgesproken tijdens de alanwarding van het ambt van hoogleraar in de bedrijfseconomie an bedrijfs kunde aan de Faculteul der Economische Wetenschappen en Bedinjfsikunde van de Universiteit Maastricht. 
zoekingen laten hierower geen misverstand bestaan. Een overtuigende samenwatting daarvan is te vinden in het boek The Human Equation: buit ding profits by putting people first ut $1998^{4}$ van de Stanford-hoogleraar Jeffrey Pfeffer. De lange-terminprestaties van ondernemingen die in hun personeel investeren, liggen beduidend hoger dan dezelfde prestaties van bedrijven die hun personeel vooral als een kostenpost behandelen. In plats van het koesteren van een kostengericht beteid van lage lonen, flexibele contracten, tijdelijke banen, hiërarchische verhoudingen en salarisongelijkheden zouden ondernemingen moeten kiezen voor een investeringstrategie van hoge lanen, vaste contracten, duurame loopbaanpaden, werknemermedezeggenschap en salariscompressie. In 1995 heeft Mark Huselid een artikel in de prestigieuze Academy of Management Journal gepubliceerd ${ }^{5}$ waarin deze aanbevelingen van empirisch bewijs worden voorzien via de meting bij bijna duizend Amerikaanse ondermemingen van een reeks prestatieverbeteringen die het moderne aandeelhouderwaardemanagement zouden moeten aanspreken: een standaarddeviatiestijging in het gebruik van maatregelen waarmee in het personeel wordt geinvesteerd, gaat per werknemer gepaard met een toeneming van de omzet met ruim 27.000 dollar, een marktwaiardewinst van bijna 17.000 dollar en een stijging van de bedrijfswinst met ongeveer 4.000 dollar. Daar kan een reorganisatie- en/of saneerprogramma slechts zelden tegenop. Het koesteren van menselijke software legt individuele ondernemingen zeker geen windeieren.

Opvallend is dat vergelijkbare geluiden inmiddels worden geventileerd vanuit de bedrijfswereld zelf. De voorbeelden van recente onderzoekbevindingen van de Britse tak van de $A B N$ Amro Bank en het wereldwijde adviesbureau Boston Consulting Group zijn veelzeggend. De Britse ABN Amro Bank heeft een zogenoemde 'ABN Amro's UK Employee Ownership Index" samengesteld van 21 in Londen genoteerde ondermemingen die een beleid wan substantiële werknemerparticipatie hanteren. ${ }^{6}$ De stijging van deze index in de afgelopen viff jaren ligt ongeveer 80 procent boven die

4. Vitgegeven bij de Harvard Business School Press in Cambridge (MA).

5 The impact of human resource mamagement practices on turnover, productivity, and corporate financiall performance", Academy of Management Journal 38: 635-672.

6 Lisa Buckingham in The Guardian wan dinsd alg 4 meil 1999. 
van de gangbare Londense beursindices. Ook de bevindingen van de Boston Consulting Group op basis van een studie naar de prestaties van "s werelds vijfduizend grootste ondernemingen zijn tekenend: uiteindelijk leiden groeistrategieën tot betere beursprestaties dan hun populaire saneerpendanten. ${ }^{7}$ In deze context is het opvallend dat geen enkele van de Nederlandse saneerondernemingen is terug te vinden in de nationale beursprestatietop-tien. In de periode 1994-1999 zijn het wooral de groeiende in plaats van de sanerende grootbedrijven - zoals Aegon, Randstad; Getronics, Ahold en Heineken - die eruit springen in termen van aandelenrendement. Kortom: na verloop van tijd blijkt geduld te lonen. Investeren in groel leidt uiteindelijk tot betere prestaties dan saneren in krimp. In de woorden van de Mercer-consulenten Dwight Gertz en Joao Baptista: "no company ever shrank to greatness".

Wat vandaag eveneens niet aan de orde kan komen, is de invloed van personen op het reilen en zeilen van en binnen bedrijfstakken. Daarvan heb ik eenvoudigweg te weinig verstand. Gelukkig ben ik de enige niet. Op dit terrein is nog nauwelijks onderzoek van belang verricht. Op het niveau van aansprekende ondernemers zijn anecdotische voorbeelden eenvoudig uit de krant te plukken via een bestudering van bijvoorbeeld het Huijgens Journaal. Hoe zou de televisiewereld eruit hebben gezien zonder de inbreng van de dominante persoonlijkheden van Joop van den Ende en John de Mol? Over deze en andere aansprekende voorbeelden van opvallende persoonlijkheden in de binnen- en buitentandse bedrijfswereld worden fraaie literaire biografieën of boeiende historische beschouwingen geschreven. Daarmee is het echter niet mogelijk geworden om systematische uitspraken te doen over het belang van de persoonlijke eigenschappen van de homo sapiens in bedrijfstakken voor de ontwikkeling van alterlei bedrijfstakkenmerken. De eerste vraag die in dit verband moet worden beantwoord, is in hoeverre systematische bedrijfstakverschillen in de sfeer van menselijke sleutelkenmerken aberhaupt bestaan. Daama kan aandacht worden besteed aan de vervolgwraag: zijn dergelijke

7 "Amerikamase bedriven overtreffen Europese concurrentie: groeistrategie levert walgens onderzoek meer nendenent op dan herstructureringen' in de Wolkskramt was 14 september 1999 .

8 Grow to Be Gteat: breaking the downsizing gycle (1995. New York: Free Press). 
systematische menselijke-softwareverschillen geassocieerd met specifieke bedriffstakkarakteristieken? Hiverbij kunnen de anderzoekpijlen in eerste instantie worden gericht op eenwoudig meetbare eigenschappen op het niveau van leidinggevenden. In de wereld wan de Nederlandse advocatenkantoren is misschien vrijwel alle zeggenschap in handen van junisten die de meestertitel hebben behaald in het Amsterdam, Groningen, Leiden, Nijmegen, Rotterdam, Tilburg of Utrecht van de jaren zestig en zeventig. Gaat deze unieke samenstelling wan de Nederlandse advocatentop gepaard met het ontstaan en de instandhouding wan kartelachtige structuren? 9 In een later stadium kan vervolgens worden overwogen het onderzoek uit te breiden in de richting van moeilijk meetbare kenmerken op alle bedrijfsniveaus. Is concurrentie-aggressie op de II-adviesmarkt mogelijk mede te verklaren uit de dominante aanwezigheid van jonge en mannelije computerwhizzkids en informatiekundigen van hoog tot laag in alle IT-bedrijven?

De beantwoording van deze en andere vragen vergt het opzetten van een onderzoekprogramma dat in termen van dataverzameling buitengewoon veeleisend is. Behalve data ter zake de traditionele industrieeleconomische en -sociologische variabelen moet gedetailleerde informatie boven tafel komen in de sfeer van de menselijke bedrijfstaksoftware. Het is geen wonder dat in de onderzoekhooiberg dergelijke-menselijke. bedrijfstaksoftwarespelden nauwelijks te vinden zijn. Een uitzondering die deze regel bevestigt, is het experimentele onderzoek van Christophe Boone, Bert De Brabander en mijzelf uit 1994. ${ }^{10}$ Het is overigens veelzeg-

9 Bimmen de sociologie is venwant onderzoek gedaan via het in kaart brengen van zogenoemde interlocking directorates. Een overzicht van deze literatuur is te vinden in Scott, J. (1997) Comorate Business and Capitalist Class (0xford: Oxford Wniversity Press).

10 De onderzoekresultaten zijn terug te winden in een drietal artikelen: (i) Boone, $C_{.}, B$. De Brabander \& $A_{4}$ van Witteloostuijn (1999) The impact of personality on behavior in five Prisoner's Dilemma games", Joumal of Economic Psychology $20: 343-377$; ("i) Boone, C., B. De Brabander \& A. van Whtteloostuijn (1999) "Locus of control and strategic behaviour in a prisoner's dillemma glame" . Personolity and Individual Differences 27: 695-706; en (iii) Boone: C. \& A. valn Witteloostuitin (2000) "Competitive and opportunistic behavior in a Prisoner's Dilemma game experimental evidence on the impact of culture and education" ${ }^{\prime \prime}$ Scandinavion Joumal of Management 15 : $33-350$. 
gend dat ik voor een voorbeeldonderzoek moet teruggrijpen op een kleine tabel waarnaar ik tijdens mijn oratie in 1994 terloops heb verwezen. ${ }^{11}$ Ongeveer veertig Mastrichtse bedriffseconomiestudienten hebben ongeveer zes jaar geteden een drietal interactieve Bertrand-duopoliespellen gespeeld. In elk (gestandaardiseerd) spel moesten de studenten twalf keer een prijsbeslissing nemen. Hierbij kunnen de "bedrijfstakken" van twee studenten belanden in een prijzenoorlog of een kartelvrede. In het eerste geval zijn lage prijzen en grote verliezen troef, terwijl in het tweede geval hoge prijzen en dito winsten hoogtij vieren. Afhankelijk van de combinatie van menselijke eigenschappen van beide spelers kunnen de ene of de andere concurrentiekemmerken de boventoon voeren.

In deze context zijn twee voorbeelden van de invloed van spelerkenmerken illustratief. In de eerste plaats zijn de "bedrijfstak'uitkomsten sterk afhankelijk van de softwarekenmerken van de homo sapiens in termen van de persoonlijkheidstrek "locus van controle' 12 op een 'markt" met twee interne beslissers worden gemiddeld 48 hoge prijzen gesteld, terwijl in "bedrijfstakken' met twee externe spelers slechts gemiddeld 15 mal voor de hoge prijs wordt gekozen. Kortom: 'externe' markten verzanden "in een prijzenoorlog, terwijl 'interne' bedrijfstakken een kartelvrede weten te handhaven. In de tweede plaats is de invloed van opleiding veelzeggend. De studiepakketten van bedrijfseconomiestudenten kunnen sterk verschillen in termen van het aantal 'harde' en "zachte" cursussen dat erin is opgenomen. In 'harde' cursussen worden allerlei aspecten van concurrentiegevechten bestudeerd, terwijl in "zachte" blokken de nadruk wordt getegd op de rol van samenwerking; in "harde" modulen staan vooral economische inzichten centraat, terwijl in "zachte" cursussen veel aandacht uitgaat naar noties uit de psychologie. De experimentele bevindingen zijn weer pregnant. In 'zachte' bedrijfstakken wordt

11 Lat duzend bloemen bloeiem: tolerantie in en rond organisaties (1994, Amstardam f Schoonhovem: Academic Serwice).

12 Deze persoontijkhaidstrek, en de consequenties envan woor giedrag, is uitvoerig toegelicht in Boone, C. (1999) Menselikke hardware van individuen an organisaties (1999), rede uitgesproken tijdems de aanvarding wan het ambt van hooglevar in de bedriffseconomie en bedrijfiskunde aan de Faculteit der Economische Weter schappen en Bedriffikunde van de Universiteit Mastricht. 
regelmatig de kartelvrede gehandhafid via in total 43 hoge prijsstellingen. Op tharde" markten zijn prijzenoorlogen schering en inslag met slechts 26 hoge prijzen. Zelfs binnen een verhoudingsgewijs homogene gruep bedrifseconomiestudenten wordt het gedrag in belangrijke mate beinwloed door het 'harde' of 'zachte' profiel van de afgeronde keuzevakken, met alle gevolgen van dien voor bedrijfstakkenmerken.

De aansprekendle anecdotes en experimentele resultaten wijzen erop dat de eigenschappen van de menselijke software van sleutelfiguren mogelijk van grote invloed zijn op de ontwikkeling van bedrijfstakken. In het licht van het opleidingresultaat kan de vraag worden gesteld welke invloed moderne managementopleidingen uitoefenen op het reilen en zeilen van en binnen bedrijfstakken. De moderne managementelite en het dito talent gaan door dezelfde mollen van adviezen, ervaringen en opleidingen. ${ }^{13}$ Hierbij gaat het miet alleen om de gemeenschappelijke kennis die wordt opgedaan gedurende de reguliere opleidingen aan onderwijsinstellingen in tegendeel. Op de MBA-markt groeien de bomen tot aan de hemel. In navolging van de grote Amerikaanse en Europese voorbeelden - de Harvarden en INSEADen van deze wereld - heeft inmiddels elke zichzelf respecterende universiteit en $\mathrm{HBO}$-instelling een $M B A$-opleiding "in de markt gezet" ten behoeve van het naar kennis smachtende komende of gearriveerde managementtalent. Daarnaast kan uit een eindeloze reeks "op maat gesneden" kortlopende cursussen worden gekozen. Dezelfde universiteiten en $\mathrm{HBO}$-instellingen hebben daarvoor gerichte satellietondernemingen in het leven geroepen die krachtig moeten concurreren met een lange nij van commerciële opleidingenbureaus. Geen onderwerp en geen hype of de liefhebber kan ergens terecht. Vaak hoeft het managementtalent daarvoor de deur niet meer uit. Omdat gemak de mens dient, zijn in-company trainingen schering en inslag. Enkele ondernemingen zijn inmiddels zelfs overgegaan tot de oprichting van een eigen universiteit. op deze sthier grenzenloze markt van opleidingen ten behoeve van mana. gement development worden alle Angelsaksische managementhypes met

13 De oplomst en ondergang van "harde" en "zachte" managementhypes volgt een opvallend cyclisch patroon. Zie hilerover Abrahamson, E. (1997) The emergence and prevalence of employee management rhetorics: the effects of long waves, labor unions, and turnover, 1875 to 1992', Academy of Management Journal 40:491-533. 
verve gedoceerd. Vaak is de invloed nog directer: de markt van managementadviezen groeit immers als nooit tevoren. En ondanks de eigenzinrìge verpakking van de boodschap in bureauspecifiek jargon is moeitojk wol te houden dat Arthur Anderson andere adviezen verstrekt dan Mckinsey. Geen wonder dat de gedragingen en kenmerken van Nedeylandse ondernemingen en bedrijfstakken convergeren in de richting van het Angelsaksische ijkpunt.

Een gerelateerd onderwerp waarower ik vandag ook niet verder wil uitweiden, is de verspreiding van het mondiale anorexiosaneer- en reorganisatievirus in samenhang met de resulterende ondergraving van het roemuchte poldernodel. Daaraan heb ik immers mijn diesrede van 1997 gewijo ${ }^{14}$, die daama in 1999 nog is gevolgd door de publicatie van een veel te dikke polemiek ${ }^{15}$. Sindsdien heeft de wereld overigens niet stilgestaan. De ene na de andere manifestatie van het anorexiasyndroom, en de consequenties daarvan, heeft in het afgelopen jaar de financielle voorpagina's gehaald. Opvallend is vooral de recente opschudding die in de Europese motoreconomieën Duitsland en Frankrijk het financieel-economische nieuws lange tijd heeft gedomineerd in reactie op enkete typisch Angelsaksisch-geinspireerde bedrijfsincidenten. De dag nadat de Franse banderproducent Michelin had aangekondigd dat 10 procent van het Europese personeel de wacht werd aangezegd ondat een winststiging van 20 procent te mager is, vloog de koers van de Michelin-aandelen met ongeveer 12 procent omhoog. Lionel Jospin en de zijnen waren not amused. ${ }^{16}$ Zij zien zich gesterkt in hun opvatting dat het Franse karakter van de economische ordening moet worden beschermd tegen ongewenste Amerikaanse invloeden.

14 De anorexiastrategie als moatschappelijke kwal: de bedreiging van de homo sapiens in het bedrijfsleven, rede uitgesproken tijdens de 21ste Dies Natalis wan de Universiteit Maastricht op 10 januari 1997.

15 De anorexiastrategie: over de gevolgen van saneren (1999, Ansterdam / Antwerpen: De Arbeiderspers).

16 "Michelin verweert zich tegen knitiek op sanering" in MRC Handelsblad van 13 september 1999 en Sommer, M. 'Dekolonisatie Franse economie' in de Volkskrant van 16 september 1999 . 
In de herfst van 1999 is echter vooral Duitsland in rep en roer geraakt. Het bijna-fallissement van bouwbedrijf Holzmann en de bijna-acquisitie van telecomgigant Mannesmann hebben Gerhard Schröder cum suis wakker geschud. ${ }^{17}$ De Neue Mitte van de SPD van Gerhard Schröder bijkt bij nader inzien toch een ander gezicht te hebben dan de Third Way van het Britse New Labour van Tony Blair. De Angelsaksische laissez-faire-interpretatie van het marktka pitalisme latat zich immers moeilijk verenigen met de Rijnland-versie die lange tijd Duitsland en ommestreken, inclusief Nederland, hebben gekenmerkt. In reactie op de dreigende (vijandige) overneming van Mannesmann door het Amerikaans-Britse Vodafone zijn alle vergeten tegeisstellingen tussen het Angelsaksische systeem en het Rijnlandmodel weer luid en duidelijk op tafel gekomen. Het dreigement van DaimlerChrysler om het hoofdkantoor te verplaatsen naar de Verenigde Staten lijkt de voorbode te zijn geweest van een invasie van de Amerikaans-Britse machomanagementstijl. Het Angelsaksische aandeelhouderkapitalisme is daarom weer oudlerwets de oorlog verklaard. Het gezamenlijke pamflet van Tony Blair en Gerhard Schröder over de Third Way / Neue Mitte is nijp voor de papierversnipperaar. Op de Holzmannbarricaden is Gerhard Schröder tot het inzicht gekomen dat de Angelsaksische hardvochtigheid onverenigbaar is met het Rijnlandse consensusstreven. Krijgt de Franse premier Lionel Jospin alsnog het gelijk aan zijn kant? Of is de mondialisering van het Angelsaksische aandeelhouderkapitalisme onstuitbaar?

Een sleutelkenmerk van het aandeelhouderkapitalisme is de concurrentiè-georiënteerde organisatie van de omgang binnen en tussen bedrijven. De mondiale verschuiving in Angelsaksische richting raakt daarmee het hart van de nationale culturen van de continentaal-Europese samenlevingen. De conflictbenadering komt in de plaats van het consensusstreven. Deze consequentie is direct zichtbaar in de wijze waarop binnen bedrijfstakken ondernemingen met elkaar omgaan. In een recensie in NRC Handelsblad van vrijdag 20 december 1996 van een tiental representatieve mariagementboeken typeert Hubert Smeets ${ }^{18}$ de oorlogzuchtige taal die

17 Ward, M. de "Afscheid van Deutschland AG: mobititeit wan het kapitaall stelt het consensusmodel op de proef in NRC Handelsblod var 26 november 1999. 
de vooral Amerikaanse management'filosofen' uitkramen, als volgt: "Op de huidige markt is geen sprake meer van een gewoon gevecht maar van 'brute strijd' (Jack Welch van General Electric). Simpele concurrentie? Nee, de concurrentie is "fel, moordend, bikkelhard en barbaars" (Robert Crandall van American Airlines). Men is 'zakelijk in ooriog en dit is de vijand" (Paul Stem van Northern Telecom).... We verkeren thans in "hyperconcurrentie" waarin iedereen is 'geneutraliseerd" en alleen een 'verrassingsaanval' nog uitkomst kan bieden (Richard D'Aveni van Amos Tuck School of Business). ... Slechts wie deze 'dynamische dialectiek' doorstaan, hebben de 'vallei des doods getrotseerd' en zullen sterker uit de 'beteugelde chaos' tevoorschijn komen (Andrew S. Grove van Intel Corporation)" Geen wonder dat ook de kiem van de anorexiasaneerstrategie in de Verenigde Staten is gelegd. De effectieve aanval- en verdedigingstrategie in de zakelijke concurrentie-oorlog is immers snel gevonden: "Mean and lean' (link en lenig) is daarbij het evangelie. Hetgeen er veelal op uitdraait dat deze ondernemingen in een spiraal van sanering-op-sanering terecht komen. ... Maar daardoor draait nagenoeg iedereen door deze permanente reorganisaties dol". De volgende stap is daarom revolutie. "Dat is volgens Hamel de filosofische fundering van vandaag: "strategie is revolutie, al het andere is tactiek". Deze revolutie moet worden volbracht door de "alles" wetende elite" van de "nieuwe managerswoorhoede". De cirkel is rond: de redders van het marktkapitalisme moeten zich gedragen als Bolsjewistische revolutionairen! De geschiedenis is weer eens cynisch.

De gevolgen van deze ommekeer voor de menselijke software van de voormalige harmonie-economieën zijn verstrekkend. Bij wijze van voorbeeld is het interessant de blik te richten op de Amerikanisering van bedrijfsculturen. Vijandig acquireren en hardvochtig saneren staan symbool voor de machostijl van management die in de Verenigde Staten tot geloof is verheven. Via strakke hiërarchische lijnen worden orders verzonden. Amerikaanse ondernemingen vertonen sterke gelijkenis met een leger. Het hoofokwartier is de beschermde bunker waarin de generale staf de nieuwe marsroute uitzet. Via een lange reeks van onderofficieren worden wervolgens de artillerie en infanterie aan het werk gezet. Voor aarzeling,

18 'Een herwalardering van een stootarbeidier'. 
Laat stain tegenspraak, is geen tijo. Een Amerikaanse ondememing schaant zich ervoor wanneer nog altijd vakbonden op de werkwloer actief zijh. De oorlog woedt niet alleen tegen concurrenten, maar ook tegen vakbonden. Beide moeten worden verslagen. Over beide moet macht worden uitgeoefend. De machostijl wan leidinggeven heeft verregaande consequenties woor de opbouw van de onderneming. Een leger vraagt om een hërarchie. Mocht de piramide niet al lang geleden aan de oevers varn de Nijl zijn uitgevonden, dan zou het Amerikaanse bedrijfsleven alsnog deze parel aan de wereldarchitectuur hebben toegevoegd. Een piramide moet natuurlijk worden gevuld. Wat is immers een tiërarchie zonder rangen en standen? Een werknemer moet orders ontvangen en uitwoeren. Iemand moet de orders doorgeven, en iemand moet vervolgens de uitwoering ervan bewaken. Dat geldt ook voor de sergeant, kapitein, luitenant, majoor en kolonel. Iedereen zijn eigen superieur. De bas-zijn in een grote onderneming kan alleen met een leger van adjunct-, onder- en subbazen. Het gevolg van de machostijl is dan ook een fijnmazige opstapeling varn managementlagen: geen grotere bureaucratie dan de Amerikaanse onderneming! In het Amerikaanse bedrijfsteven werden in 1989 ongeveer 17 miljoen bazen van het ene of het andere type aan het werk gehouden. Het bedrag dat jaarlijks wordt overgeboekt ter beloning van dit officierencorps, is plusminus vier keer hoger dan het budget dat de federale overheid ter beschikking heeft gesteld ten behoeve van de sociale zekerheid. Over de tweede rekening wordt moord en brand geschreeuwd: de uitgaven aan de sociale zekerheid, aldus de critici uit Republikeinse en bedrijfskringen, leggen de bijl aan de wortel van de Amerikaanse economie over de eerste rekening is niemand te horen.

Met de machostijl worden de officieren gekoesterd en de soldaten geknecht. De machostij! heeft ertoe geleid dat de werkvloer moet bloeden via baanverlies, Loonval en werkdruktoeneming. Natuurlijk kan worden aangevoerd dat zulks onvermijdelijk is in moderne concurrentietijden. Marktkapitalisme vaagt om een machostijl: zachte heelmeesters maken immers stinkende wonden. Ondernemingen die niet strak worden geleid. conform de oorlogmetafoor, zijn gedoemd kopje onder te gaan na aanwijzing door de onzichtbare selectiehand. Deze gedachtengang impliceert 
dat de Verenigde Staten niet alleen staan: alle Westerse economieèn die zich succesvol weten te handhaven in de mondiale concurrentiestrijd, hebben te maken met een 'volwassen' managementapparaat. Zonder de bureaucratische last wan een officierencorps is het leger immers onstuurbaar. Zonder een weloverwogen bouwwerk met managementlagen is een onderneming stuurloos. De vraag is daarom in welke mate het Westerse bedrijfsleven adjunct-, onder-en subbazen in dienst theeft. Hoeveel banen worden in Westerse economieën gereserveerd voor management- en management-gerelateerde functies? In zijn postuum verschenenen boek Fat and Mean: the corporate squeeze of working Americans and the myth of maragerial 'downsizing' uit $1996^{19}$ schetst de Newyorkse macro-econoom David Gordon een beeld van de bureaucratische last in de Verenigde Staten in vergelijking met die in een aantal andere Westerse economieen in 1989. De bureaucratische last is gemeten wia het procentuele aandeel van management- en administratief personeel in de niet-agrarisiche werkgellegenheid.

De verschillen zijn enorm. De Verenigde Staten en Canada steken met kop en schouders boven de rest uit met percentages van 13,0 respectievelijk 12,9 procent. In bijna alle niet-Angelsaksische landen ligt het percentage managementbanen tussen de 2,5 en 4,5 procent. Alleen in Noorwegen is de bureaucratische last wat hoger met 6,8 procent. Nederland walt niet op met een percentage van 4,3 procent. De machostijl is blijkbaar eerder Amerikaans dan kapitalistisch. In een Intermediair in 1997 merken de Rijnconsult-directeuren Theo Camps en Teun van Aken hierover op dat "[d] Amerikaanse samenleving is doortrokken van het idee dat er leiders en volgers zijn. ... Amerikaanse managers verwachten van uitvoerders geen initiatieven. In de VS wordt een opdracht miet ter discussie gestelld". ${ }^{20}$ De voornoemde getallen zijn echter van 1989. Dat is al weer lang geleden. Inmiddels heeft het saneervirus immers zijn weg gevonden naar het mondiale grootbedrijf. Wat is met de Amerikaanse bureaucratische last gebeurd in de jaren negentig? De communis opinio is weer weinig verrassend. Een representatieve verwoording ervan is te vinden in Business Week van 23 maart 1992 door Bruce Nussbaum: "After years of

19 Verschenen bij de Free Press in New York. 
layoffs, the specter of downward mobility is haunting legions of once-secure managers and professionals". Met andere woorden: saneringen moeten hebben geleid tot een afneming van de bureaucratische last ten gevolge van het schrappen van overbodige managementfuncties en -Lagen in de eindeloze rij wan re-engineerende en sanerende ondememingen. Juist het Amerikaanse bedrijfsleven had en heeft de mond vol van de noodzaak tot de bevordering van flexibribiteit en lenigheid: het owertollige vet moet eraf. De wegen van het machomanagement kunnen echter ondoorgrondelijk zijn: in de jaren negentig is in de Verenigde Staten de bureaucratische last gestegen tot voorlopig 13,6 procent in het tweede kwartaal van 1995. In de jaren 1991-1995 is 26,6 procent van de banengroel buiten de agrarische sector in managementfuncties te vinden geweest. De saneringen hebben blijkbaar niet de bekritiseerde managementfunctionarissen getroffen, maar wooral de man of vrouw op de werkvloer. De machosaneerstijl heeft in de jaren negentig de bureaucratisering wan en conflictcultuur binnen het Amerikaanse bedrijfsleven verder verscherpt. Gaan de Duitse en Nederlandse ondernemingen dezelfde kant op door het Rijnlandse harmoniemodel te vervangen door de Amerikaanse conflictcultuur, met alle gevolgen van dien voor het karakter van de menselijke software van deze voormalige harmonie-economieën?

De bestudering van de menselijke software op het niweau van economieën is een buitengewoon boeiend studieterrein. Een ander thema waarover ik vandaag graag in dit verband met $U$ van gedachten zou hebben willen wisselen, is de rol van menselijke software in de nieuwe informatie-, kennis- en/of netwerkeconomie. Daaraan kan ik echter niet beginnen, het wordt eentonig, omdat andere economen - met mijn BrusselsMaastrichtse collega Luc Soete fier voorop - daarvan veel meer verstand hebben. Wie tegenwoordig echter zwijgt over de consequenties van de informatierevolutie, wordt niet voor vol aangezien. Helaas: pas na ten minste een jaar verdere studie ben ik eraan toe om gefunderde uitspraken te doen over de gevolgen van de informatisering van economie en samen leving voor het verloop van concurrentieprocessen binnen bedrijfstakken en de macro-economische ontwikkelingen van economieën. Het is inmid-

20 Lof, E. (1997) 'Nederland denkt niet genoeg na' in Intermediair 33 (50): 49-51. 
dels overigens gemeengoed om aan te nemen dat de introductie van de modeme informatie- en communicatietechnologieèn zal leiden tot de bloei wan nieuwe bedrijfstakken, een stijging van productiviteiten en een macro-economische groei-impuls. Het lijkt mij evident dat de nieuweconomische informatie-, kennis- en netwerkontwikkelingen daamaast de eerder genoemde effecten zullen versterken. In een recente Intemediair wijst Luc Soete in dit verband op enkele pregnante keerzijden van het nieuw-economische sprookje. Vooral de kop boven het vraaggesprek is veelzeggend: "J'Je gaat failliet of wordt schatrijk" $k^{\prime \prime} 21$

Op het niveau van economieën vraagt deze keerzijde van de nieuwe informatie-economie om een krachtig antwoord via een herijking van het concurrentiebeleid, een hervorming van het eigendomsrecht en een investering in de informatie-infrastructuur. Het is treurig dat juist in de sfeer van investeringen in de materiële en immateriële infrastructuur de prestaties van polderwonderland Nederland teleurstellend zijn. De macro-economische investeringen in onderzoek en ontwikkeling zijn in de afgelopen twaalf jaren gestaag gedaald van 2,28 procent van het bruto binnenlands product in 1987 tot 1,67 procent in 1996. Het bedrijfsleven is na het hoogtepunt van 1,35 procent van het bruto binnenlands product in 1987 afgezakt naar 0,99 procent in 1994.22 Mijn hypothese is, het zal U nauwelijks verrassen, dat de kortademige druk van de aandeelhouder ertoe heeft geleid dat voortdurend hogere rendementeisen worden gesteld aan investeringsprojecten. Het gevolg daarvan is dat strategieën die direct de beurs tot enthousiame prikkelen, met name afslankoperaties en bedrijfshandel, worden geprefereerd boven lange-termijninvesteringen in onzekere onderzoek- en ontwikkelprojecten. De inspanningen van de overheid versterken deze neerwaartse ontwikkeling in het niveau van de macro-economische investeringen in onderzoek en ontwikkeling. De publieke onderzoekinvesteringen zijn teruggelopen van 1,11 procent van het bruto binnenlands product in 1987 tot 0,83 procent in 1999.23 ook de

21. Bart van 0osterhout in Intermediair $35(48): 32 \cdot 33$.

22 Deze informatie is afkomstig wan het Nederlands Observatorium wan Wetenschap an Technologie en Veel top, geen geld" in NRC Handelsblod van 1.4 malnt 1998.

23 Delft, 0 . van "Tien mitjoen is geen bedrag": WWO wil forsere lmpuls warnieuwing wetenschappelijk onderzoek in NRC Handelsblad wan 9 oktober 1999. 
nationale investeringen in de mensetwke software, onmisbar in de nieuwe kenniseconomie, bliven ver achter bij poldemondervoorspoed. Deze constatering geeft mij getuking alle gelegenheid on een meuw couplet toe te voegen an de obligate klagzang over het Nederlandse onderwijbeleid, die onlosmakelijk is verbonden met een afscheidstede. De erie na de andere begroting wan het Ministerie van Onderwijs, Cultur Wetenschappen koppett immers fraaie woorden aan kille bezunigingen. In zun Latste begroting schreef Minister Jo Ritzen bezielend ambtetijk proza over de kerniseconomie wan de 21ste eeuw. In zin regeerperiode is de omvang van de onderwijsbegroting echter verder gedaald van 5,8 procent van het bruto national product in 1992 naar 5,3 procent in 1996. 24 In 1988 lag dit percentage nog op 6,6 procent. Zijn opvolger Loek Hermans zet deze bijn door met weel mooie woorden zonder bybehorende budgetstijgingen. Het resultat is dat de Nedertandse onderwijsuitgaven ver onder de OESO-norm van zes procent van het bruto national product bljwen. 25 Het Nederlandse onderwijsbudget steekt hiemee schril af bij dat in andere Westerse Landen.

Veel onderwerpen die k vandaag niet met $U$ kan of wil bespreken, wijzen in dezelfde richting: de machomanagementstijl binnen organisaties, het Angelsaksische karakter wan de managementopvoeding, de verspreiding wan het aandeethouderkapitalisme en de opkomst van de nieuwe informatie-economie leiden tot een versterking van de tweedeling in de samentewing. Zeker in Noord-Zuidverband spreken de feiten boekdelen. De laatste twee decennia van het tweede millennium worden immers gekenmerkt door een scherpe verdieping van de kloof tussen arm en rijk. Het gat tussen het rijke Noorden en het arme Zuiden wordt dieper en dieper. Het gecombineerde vermogen wan de multimiljardairs Bill Gates (Microsoft). de Walton-familie (Wal-Mart) en de Sultan wan Brunei (van plusminus 270 miljard gulden) is groter dan het jaarlijkse geaggregeerde inkomen wan 600 miljoen armen in de Derde Wereld. De 200 rijksten der aarde hebben hun vermogen in de afgelopen vier jaren zien verdubbelen tot 2.000

24 "Kenniseconomie" in WRC Handelsblod van 17 nowember 1997.

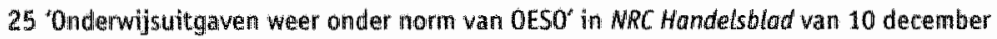
1997. 
miljard gulden, terwill nog altijd 1,3 miljard weretdburgers moeten zien rond te komen van minder dan twee gulden per dag. Dertig jaar geleden was de verhouding tussen de twintig procent rijksten in de wereld en de twintig procent armsten $30: 1$; in 1990 was deze kloof opgelopen tot 60 : 1* en vandaag staat de teller op $74: 1{ }^{26}$ Ook binnen de rijke Westerse economieën wordt de tweedeling jaar na jaar scherper. In de Verenigde Staten van de Democraat Bill Clinton was het inkomen van het modale Amerikaanse gezin in 1998 vier procent lager dan in 1989. 27 Sterker nog: 80 procent van de Amerikaanse bevolking is sinds 1973 geconfronteerd met een daling van het reële inkomen. ${ }^{28}$ In het Verenigd Koninkrüjk van de socialist Tony Blair laat de gezondheid van de miljoenen kinderen wit Britse working-classgezinnen even veel te wensen over als die van de Albanese jeugd. ${ }^{29}$ En helaas weet ook het Nederland van de sociaal-democraat Wim Kok miet te ontkomen aan deze neerwaartse spiraal van voortschrijdende denivellering. Het CPB is erachter gekomen dat het reele inkomen van de Nederlandse Jan en Mien Modaat het afgelopen jaar met 0,25 procent is afgenomen. In de Volkskrant van donderdag 16 september moesten acht Tweede-Kamerleden van uiteentopende snit toegeven dat de verdeling van de Nederlandse welvart te scheef is. ${ }^{30}$ Daar staat tegenover dat de kleine groep steenrijken geen tijd heeft om te waren in de na de verzilvering van deze of gene "prestatieprikkellende" optieregeling gekochte jachtschepen.

Is deze onstuitbare beweging in de richting van toenemende tweedeling de onvermijdelijke prijs die moet worden opgebracht voor de komst van het mondiale informatietechnologische aandeethouderparadijs? Vermoedelijk (en hopelijk) niet. Helaas is de informatierevolutie een locaal fenomeen. Immers: 75 procent van de noodzakelijke telefoonlijnen is te vinden in het rijke Westen (ten behoeve van slechts 17 procent van de

26 'UKH attacks growing gulf between rich and poor in The Guardian van 12 jult 1999.

27 From boom to gloom in Detroit city: the good, the bad and the ugly" in The Guordian van 30 juni 1999.

28 Gordon, 0. (1996) Fat and Hean: the corporote squeeze of working Anthericons and the myth of "managerial" downsizing (New York: Free Press).

29 What did you do during the dock strike?" in The Guardian van 13 jull 1999.

30 Arnoedeprobleem is onvangrijker dan we denken". 
wereldbevolking). En ook in dat rijke Westen gaan de zegeningen van het informatietechnologische wereldwonder voorbij aan grote delen van de samenteving. In veel opzichten is de architectuur van de wereldeconomie in verval Zelfs het nieuw-economische wonder in de bovenlagen van de Westerse samenlevingen is gebaseerd op een zeepbel. De Amerikaanse economie bloeit op de pof. Na een ineenstorting wan Wall Street valt het kartemhuis in elkaar. ${ }^{31}$ De tweedie helft van de jaren negentig heeft in de vorm van het Dost-Aziatische voorbeeld laten zien welke economische en socialle ravage daarvan het gevolg is. Volgens Larry Elliott, de economieredacteur van het gerespecteerde Britse dagblad The Guardian. is "[t]he millennium ... not ending with a settled and prosperous world but with instability bordering on anarchy". ${ }^{32}$ Dat zijn zware woorden. Overdreven? - ik wrees van niet; onvermijdelijk? - ik hoop van niet. De Britse hoogleraar Robin Marris heeft recentelijk een pleidooi gepubliceerd ten faveure van de herinrichting van de mondiale economische orde onder de titel Ending poverty. ${ }^{33}$ De inondiale economische architectutur kan worden versterkt via drastische hervormingen van het ongebreidelde aandeelhouderkapitalisme, inclusief de introductie van een Tobin-belasting op valutaspeculatie en een krachtige mondiale centrale bank. De kans dat de locaal-mondiale informatierevolutie wordt geleid met behulp van deze en andere radicale hervormingen van de economische wereldorde, is echter niet groot. In de woorden van de steenrijke CNN-eigenaar Ted Tumer: "It is as if globalisation is in fast forward, and the world's ability to understand and react to it is in slow motion" 34

Het zat $U$ ongetwijfeld zijn opgevallen dat mijn bespreking van deze moderne ontwikkelingen is doorspekt met normatieve uitspraken. Hiet belang van een geẻngageerde economiebeoefening kan, wat mij betreft, niet genoeg worden benadrukt. Aan een pleidooi hierwoor begin ik vandaag echter niet. Daarvoor is deze vorm van economiebeofening te weinig wetensthappelijk. Met enige regelmat word ik geconfronteerd

31 Witteloostuighn. A. van 'De keerzijge van het succes' in de Wolkskrant van 21 Septenber 1999.

32 "Mr Turner abhors a wacuum" in the Guardian van 12 jult 1999.

33 Uitgegeven in 1999 by Thames \& Hudson in Londen.

34 ine noot 32 . 
met denigrerende tegenwerpingen: de wetenschapper wordt geacht zich vol toewijding te beperken tot fundamenteel-wetenschappelijk onderzoek ten behoeve van de productie van A-publicaties met het oogmerk door te dringen tot de Intermedioir top-40. Natuurlijk moet ivoren-torenonderzoek worden gekoesterd. Sterker nog: ik hoop dat de vermoeiende discussie over het maatschappelijk nut van wetenschappelijk onderzoek binnen afzienbare tijd tot het stoffige verleden van de marktjaren tachtig en negentig behoort. Deze constatering laat echter onverlet dat de universitaire wereld zich kan en moet mengen in matschappelijke debatten. In het maatschappelijke en wetenschappelijke debat over de grote veranderingen en uitdagingen in de samenleving van de 21 ste eeuw kan een actieve bijdrage vanuit de universitaire ivoren toren een creatieve sleutelrol spelen. Deze creativiteit vraagt naar mijn overtuiging om onconventionele bijdragen. Hoewel ik een groot liefhebber ben van onconventioneel gedrag, is het niet gepast daarover te spreken tijdens een plechtige bijeenkomst als die vam vandaag. Daamaast heb ik mij, in alle eerlijkheid, nooit in deze materie verdiept. Mij dunkt dat onconventioneel gedrag echter het sleutelkenmerk is van de creatieve ondernemer en dito wetenschapper.

In de managementliteratuur, en ook elders, zujn interessante bewindingen gerapporteerd ower het nut van afwijkend gedrag in de context van organisatie-innoveren, - leren en -presteren. De resultaten van onderzoek naar de determinanten van (duurzame) concurrentievoordelen zijn in dit verband veelzeggend. Een concurrentievoordeel bestaat bij de gratie van unieke kenmerken. De schepper van dergelijke unieke kenmerken is uiteindelijk de homo sapiens. Zonder de cruciale rol van mensen blijven de uitvinding van nieuwe technologieën, de ontwikkeling van nieuwe producten en het ontstaan van nieuwe bedrijfstakken uit. Daarom is het broodnodig te investeren in de menselijke software van individuen, organisaties, bedrijfstakken en economieën. Een woorbeeld van deze gedachtengang is te vinden in het boek De levende ondememing: over leven en leven in een turbulente omgeving $(1997)^{35}$ van de voormalige Shell-strateeg Arie de Geus. Arie de Geus is betrokken geweest bij een grootschalig onderzoek naar oeroude ondernemingen: hoe is het mogelijk

35. Uitgegeven bij Scriptum Managenent in Schiedam. 
dat een mammoetonderneming als Koninklijke olïe / Shell die ene na de andere revolutie heeft overleefd? Zijn antwoord op deze vraag stat in scherp contrast met het beleid van de Shell-presidenten van de jaren negentig. De verklaring klinkt weer als een open deur: evenals Jeffrey Pfeffer maakt Arie de Geus duidelijk dat de crux te vinden is in de zorg woor de homo sapiens. Ook Arie de Geus benadrukt het belang wan bij voorbeeld terughoudendheid met saneringen, het gevaar van zelfverrijking, de ontwikkeling van het personeel, het nut van interne promotie $e_{i}$ de vertrouwenwekkende werking van lange-termijncontracten, de bijdrage van gezamenlijke scholing, de meerwaarde van het werken in tearnwerband en de noodzaak tot medezeggenschap. Aan het "Pfefferiaanse' rijtje woegt hij een par elementen toe. Twee yoorbeelden daarvan zijn personele heterogeniteit en culturele tolerantie. Zonder deze eigenschappen 'Leeft' een onderneming niet. Een werknemer moet zonder angst met nieuwigheden kumnen experimenteren. In heterogene en tolerante ondernemingen vinden in de marge legio van dergelijke experimenten plaats. Uit deze bron van creativiteit worden organisatie-, proces- en productinnovaties geboren. Met de huidige populariteit van de machomanagementstijl wordt het tegendeel bewerkstelligd.

De reeks van onderwerpen waarover ik vandaag niet heb kunnen of willen spreken, samen met wat mijn collega Christophe Boone well heeft gezegd, impliceert een pleidooi voor de verdere untbouw van een onderzoekprogramma ter zake de invloed van menselijke eigenschappen op de gedragingen en prestaties van individuen, organisaties, bedrijfstakken en economieën. Een dergelijke onderzoeklijn kan uiteraard profitteren van de rijke kennis die is opgebouwd binnen allertei deelterreinen wan de mensen maatschappijwetenschappen. Door echter nieuwe vragen te stellen en nieuwe antwoorden te zoeken vanuit een multidisciplinair perspectief kan enorme vooruitgang worden geboekt. Het is mijn overtuiging dat vanuit de Maastrichtse Faculteit der Economische Wetenschappen en Bedrijfskunde aan deze multidisciplinaire onderzoeklijn een belangrijke impuls kan worden gegeven.

Waar ik vandaag wel bij wil stilstaan, is het bedanken van de Maastrichtse en Zuid-Limburgse entourage die ervoor garant heeft gestaan dat ik kan 
terugkijken op twaalf buitengewoon plezïerige en productieve jaren. De Universiteit Maastricht en de Faculteit der Economische Wetenschappen en Bedrijfskunde zijn het levende bewijs van het nut van afwijkend gedrag. Beide leveren topprestaties, en beide hebben zich een indrukwekkende pionierrol toegeëigend. De Universiteit Maastricht is immers de imovatieve instelling die vroeg het probleem-gestuurd onderwijs heeft geinntraduceerd, en de Faculteit der Economische Wetenschappen en Bedriffskunde is immers het dynamische economengezelschap dat vroeg het pad van internationalisering is ingeslagen. In beide gevallen zijn de successen uiteindelijk te danken aan unieke persoonlijkheden die een woorkeur voor onconventioneel gedrag aam de dag hebben gelegd, en nog altijd aan de dag leggen. En deze unieke persoonlijkheden hebben ook de ontwikkeling van en binnen de universitaire bedrijfstak verregaand beînvloed: probleem-gestuurde onderwijsvormen zijn inmididels op grote schaal in de Nederlandse universitaire wereld geïntroduceerd, en de andere bedrijfskunde- en economiefaculteiten in polderwonderland. Nederland imiteren driftig de Maastrichtse internationaliseringstrategie.

Graag wil ik van deze gelegenheid gebruik maken om de umieke organisatiecultuur van de Universiteit Maastricht te prijzen. Deze cultuur wordt gekenmerkt door een opvallende en prettige combinatie van een functionele bureaucratie, informele omgang en aandacht voor het personeel. De verpersoonlijking hiervan is Karl Dittrich. Met zijn stijl van leidinggeven staat hij garant voor een sfeer van dymamiek en openheid die buitengewoon bevordelijk is voor de facultaire en universitaire innovatiekracht. In de context van de Faculteit der Economische Wetenschappen en Bedrijfskunde wil ik een zestal unieke persoonlijkheden met ere noemen, zonder overigens de cruciale bijdrage van de honderden andere facultaire (oud-)medewerkers te willen verdoezelen: de drie pionierhoogleraren Wil Alberda, Joan Muysken en Hein Schreuder, zonder wie de faculteit een conventioneler profiel zou hebben gekregen, de bestuurder-directeur Renè Verspeek, die elke dag weer over de bijzonder facultaire organisatiecultuur wakkt, de onderzoeker-ondernemer Luc Soete, die met verve aen ambitieuze ondercoekcultuur heeft geëntameerd, en de cultuurgoeroe Geert Hofstede en de reisverslaafde Chris De Neubourg, aan wie de facul- 
teit de verregaande internationalisering te danken heeft. Zonder de andere secties tekort te willen doen, will ik een speciaal woord van dank richten tot de (oud-) ) leden van de Sectie Organisatie. In het afgelopen decennium heb ik volop kunnen profiteren van de aangename en stimulerende sfeer binnen deze anarchistische groep eclectici. Vooral mijn samenwerking met Christophe Boone zall ik mij altijd blijwen herinneren als uitzonderlijk plezierig en productief. Ik hoop en verwacht dat aan deze samenwerking nog geen einde is gekomen. Via de electronische snelweg is de afstand Groningen-Mastricht in een flits af te leggen. Uiteraard wil ik drie prachtige voorbeelden van menselijke software niet onvermeld laten: Hettie, Merel en Amber zijn drie unieke persoontijkheden die mijn leven elke dag weer verrijken. Ten slotte wil ik een woord van herdenking uitspreken. Ongeveer een maand geleden is plotseling mijn schoonmoeder, Hillie Koning-Bakker, overleden. Daarom draag ik deze rede op ter nagedachtenis van deze lieve moeder en oma.

Ik heb gezegd. 